\title{
A New Introduction: More than Three Decades of Writing on Spanish Central America, 1973-2006
}

\author{
by Murdo J. MacLeod
}

A student of the era in Central American colonial history that runs from the years just before and after the Spanish invasions of the 1520 s to the early decades of the eighteenth century soon notices several tendencies in scholarly research and publication.

One trend is that the incursions from the central Mexican base receive more attention than those starting from Panama and, later, Nicaragua. Some of the reasons for this are obvious. Colonial Panama, with some very notable exceptions, has attracted surprisingly little scholarly attention given its importance to Spanish imperial geography and economy, while colonial Mexico, with Peru one of the great centers of the first two centuries of Spanish colonialism, has produced a comparatively huge volume of work.

Another reason may have to do with what the invading bands found. The areas that became colonial Guatemala, Izalcos, and San Salvador, while minor compared to central Mexico, contained greater populations and potential wealth than Honduras, Nicaragua, and Costa Rica, where, after early boomlets, servile native labor became the leading export for some years. Thus, more Spaniards, interest, rivalry, reporting, and probably documentation emerged in and from the north and west of the whole region.

Of greater importance to any surveyor of these two colonial centuries is that he-in this case he-soon cannot fail to discover that research and writing have much favored the more recent colonial years after 1720. Scholars have devoted more attention to the later eighteenth century and to the nineteenth century before national independence. (These studies, in their turn, are less numerous than the ones dedicated to the study of the nation-states of the nineteenth and twentieth centuries.) Much of this, again, is easy to explain. Documents of almost all categories are more numerous and accessible, and the research is more "relevant" as far as present-day priorities are concerned. Moreover, for young graduate students or professors outside Central America, anxious to complete dissertations or first publications, accessibility and, even more, comparatively modern 
orthography, and thus easier paleography, are incentives to choose later colonial topics for their work.

One suspects, nevertheless, that something more nebulous but more important than relevance, access and expediency is pushing these scholarly choices away from the two early centuries in favor of later years. What may be happening is what we can call the flash of recognition. The late colonials are us. That is certainly an exaggeration; the past is indeed foreign, and attempts to understand bygone peoples and their circumstances are perforce partial and imperfect. But the turn to rationalism or skeptical empiricism; the new European and, in the Spanish world, post-Hapsburgian desire of regimes to create modern, dominant, centralizing nation-states with their attendant bureaucracies; the coeval questioning of forms of government, belief, and power for the first time, really, in the Hispanic world since the days of Juan de Mariana; the rapid acceleration in the volume and speed of material and cultural exchanges, pushed by the early stages of the Industrial Revolution in western Europe; all of this was an enormous change in worldview and introduced us to much of the modern world. No wonder, then, that the late colonial period feels instinctively familiar and indeed welcoming to many. ${ }^{1}$

There also may be preferences according to fields of modern knowledge. If it is a truism that the anthropological tradition is drawn more readily to societies more alien to itself, then researchers within that tradition will be more interested in the sixteenth and seventeenth centuries, more Indian, more "baroque" in their later stages, more classically than romantically inclined. On the other hand, those with a more economic, sociological, or political bent should prefer the late colonial or national years. None of this has been demonstrated except anecdotally and would be worthy of more study.

These generalizations lead to two additional and unanswered questions. First, why has the drift toward emphasis on the late colonial, and away from the first two colonial centuries, picked up pace in the last two or three decades? Granted, the quantity of research and publications has increased dramatically for all three colonial centuries, but the gap between the early years and the very late colonial period has demonstrably widened. Perhaps pressures to work on more modern topics have increased.

The second question is a puzzle that so far defies answers, but may be somewhat related to the research choices mentioned above. The late pioneering scholar Lesley Byrd Simpson many years ago wrote of the seventeenth century as Mexico's "forgotten century." What he really meant was the period between 1620 or 1630 and the last decade of the century. ${ }^{2}$ 
This period of neglect, when one studies the entire three colonial centuries, has shifted to slightly more modern times, and the most neglected era now, again with some notable exceptions, appears to be 1680 or so to about 1730 or 1740 . Why this should be is not known, or so it would appear, but is all the more remarkable in that the unstudied years are ones of dynastic change, a lengthy war, increased trade, especially contraband, and of a drift toward more rationalistic views, especially in elite thinking and high governmental policies. To argue that the last sad years of the reign of Carlos II, "The Bewitched," or the disruptive length of the War of Spanish Succession (1700-1713) are major reasons for this neglect is at best incomplete. The last two decades of the seventeenth century, perhaps beginning even earlier, saw a slow revival in the Spanish and colonial economies, and, in Central America at least, the long dynastic war saw surprisingly little upheaval in most people's lives among all ethnic groups.

Other factors inhibit or obstruct the study of the first two centuries of Spanish rule in our area. There are, for example, the stressful social and economic conditions under which historians living in Chiapas and the five nations have survived for many years. Endemic violence, foreign intrusions-some of them by force-economic hardship, and deep social and ethnic inequalities, have plagued Chiapas, still divided by a continuing revolt; Guatemala, where some violence continues in spite of the end of governmental repression and massacre; El Salvador, which endured a civil war; and Nicaragua, where rebel opposition to the government was armed by the United States using Honduras as a base. Only Costa Rica escaped these terrible events.

To make matters worse, professional historians work under severe handicaps. University and institutional salaries are poor, often forcing people to hold several jobs to make ends meet, and working conditions-whether teaching supplies, classrooms, or libraries or poverty and working conditions of many of the students, who can devote little attention to their studies-beggar description, and should humble historians from the U.S. and western Europe. It is little short of astounding that Central American historians have accomplished so much given the conditions under which so many of them must live.

So much for some of the general factors influencing scholarly output in these first two hundred years. Another and equally difficult task faces anyone who wishes to write a survey of the historical literature of the last three decades and more. In the 1970s, such an undertaking was just about possible. Now it is impossible to be complete. Apart from the enormous quantity of work, there are oth- 
er difficulties. Obviously, in all fields of research everywhere, good work, however defined, does not always become widely known and, conversely, less important material often achieves undeserved fame. In Central America, this difficulty is increased by the poverty suffered by many publishers, leading to small reading populations and a related lack of facilities and established presses. Some journals and books are published in print runs of only a few hundred copies, and the distribution of these few copies is sometimes left in the hands of the author because of a lack of money for advertising and mailing. Thus, many Central American publications are difficult to track down, do not come to the notice of the editors of major reviewing journals, and are not purchased by bookstores and libraries.

Compounding these problems has been the reluctance of some European universities and research institutions to supply copies of the various theses and dissertations, and others have made such purchases difficult and expensive. It has been complicated enough trying to discover unpublished work in Spain, Germany, France, Holland, Great Britain, and even in the U.S. What of Central America? A comprehensive listing of theses exists for Costa Rica, but in Guatemala, for the most part, one must search out such unpublished material from various sources and with the help of knowledgeable local researchers. ${ }^{3}$

In spite of difficulties in finding published and unpublished sources, and in spite of the increasing preference for research in the late eighteenth and early nineteenth centuries, the volume of publications about the first two hundred years in Spanish Central America has grown rapidly since 1973. It is a large region. Consisting today of six republics, if one includes the predominantly anglophone Belize, and one Mexican state, and stretching from the isthmus of Tehuantepec all the way to the Panamanian frontier, its scholarly production is dauntingly large and diverse, and difficult to encompass much less sort into fairly homogeneous subunits. ${ }^{4}$

Let us begin with several categories of publications that cover all of colonial Central America and Chiapas. Then we will discuss more specific materials and narrower topics from individual regions. The essay will finish with a discussion of the emphases, categories, and trends of the last three decades or so, adding some perhaps tentative suggestions as to the gaps that remain and the subjects that require additional or different research analysis.

There are two major publications covering all of colonial Central America that can be described as both essential and monumental. The Historia general de Centroamérica, in six volumes, edited overall 
by the distinguished historian Edelberto Torres Rivas, contains two volumes on the colonial period in the capable editorial hands of Professors Julio Pinto Soria and Héctor Pérez Brignoli, respectively. Published in the 1990s, these two tomes provide those interested with an excellent state of the art, a place to begin for all students of colonial Central America. ${ }^{5}$

Coming from a different perspective, the recent Historical Atlas of Central America by Carolyn Hall and Héctor Pérez Brignoli, many years in preparation, is a major contribution to historical geography in general. Beautifully illustrated, economically written, with uncluttered maps, charts, and tables that can replace dozens of pages of explanatory text, this atlas advances Central American historical geography to the first rank. Nor does it neglect the two centuries of interest to this essay. The Atlas is another indispensable foundation for any serious study of our area, and a Spanish edition is urgently required. ${ }^{6}$

There are several general histories of the area, which should be kept in this category. Since 1973 many single- and multi-volume general histories have been published, all of which, to varying degrees and lengths, devote attention to the first two colonial centuries. The following, listed alphabetically, is a sample: the middle volume of the three written by the late Ernesto Chinchilla Aguilar, and those by Elizabeth Fonseca Corrales, Rodolfo Pastor, Héctor Pérez Brignoli (yet again), and Ralph Lee Woodward. ${ }^{7}$

A general category that appears to have declined-again, perhaps, a reflection of the economic difficulty facing large publication projects-is that of the multi-volume documentary collection. A major event, nevertheless, was the publication of the Monumenta centroamericae historica: Colección de documentos y materiales para el estudio de la historia de la vida de los pueblos de la América Central, far more broad in geographical and chronological scope than its unfortunately named predecessor, the Colección Somoza. Compiled by Federico Argüello Solórzano and Carlos Molina Argüello, the Monumenta consists of eleven fat tomes. This enormous and valuable treasure trove of primary documents is not, of course, without its limitations. The documents are all from the Archive of the Indies in Seville, and they emphasize institutional, official, and legislative histories. The collection reaches only to 1600 , and does not even get that far in several of the tomes. Perhaps the collection will grow; volumes 12 and 13 are promised. It is hardly the fault of the set and its compilers that it has been so little used thus far. Surely news of the usefulness of the contents will eventually spread. ${ }^{8}$

Two other collections are helpful. The Libro de los pareceres de la 
Real Audiencia de Guatemala, 1571-1655 is, again, a history of officialdom but can tell us a great many things about other parts of society that caught the attention of the fiscal or the judges of the audiencia. The larger and more useful Cartas de cabildos hispano-americanos: Audiencia de Guatemala provides a window into the day-to-day transactions and preoccupations of members of the town councils in most of the cities of Central America. ${ }^{9}$

It should be noted that many authors publish transcriptions of important documents, often as appendices to their books or essays. Moreover, the leading journals in the field in Mexico, Central America, Spain, the U.S., and elsewhere from time to time print documents and commentaries on them. Among those that have done so, recent examples are: Anales de la Sociedad de Geografía e Historia de Guatemala; Antropología e Historia de Guatemala; Anuario de Estudios Americanos (Seville); Anuario de Estudios Centroamericanos (San José); Estudios de Cultura Maya (Mexico City); Lotería (Panama); Mesoamérica; Revista de Indias (Madrid); Tlalocan (Mexico City); and Yaxkin (Tegucigalpa). There are many others.

There have been some attempts to compose complete or nearly complete bibliographies of colonial Central America, the most notable, perhaps, that of Sidney David Markman. A problem with such useful efforts is that, by their very nature, they quickly become outof-date. Also, the task itself being impossible, such bibliographies tend to emphasize the materials and fields with which the compiler is most familiar. ${ }^{10}$

Of considerable benefit to all historians of Central America, preColumbian, colonial, or national in their interests, has been the series of congresses of historians of Central America, eight to date, held in the capitals of the nations of the area, plus one in Panama and none yet in Belize. As with all such meetings, the informal exchanges of news and opinions are as valuable as the formally presented papers. Unfortunately, limited resources once again have prevented the publication of most of the essays produced. ${ }^{11}$

Surprisingly few bibliographical guides exist on specific topics for all of the two hundred years in the region. One outstanding exception is Demography and Empire: A Guide to the Population History of Spanish Central America, 1500-1821 by W. George Lovell and Christopher H. Lutz. Amply documented and accompanied by incisive commentaries-and no reader will agree with every one of them, of course-this guide makes it almost superfluous to take space in this essay to survey research on demography throughout the region. ${ }^{12}$

From a general survey to specific geographical and political divisions within the area, let us now move from northwest to southeast 
through the various provinces, gobernaciones, and alcaldias mayores of early- and mid-colonial Central America. Beginning with Chiapas, now a Mexican state, it comes as no surprise that mostly Mexican scholars from Mexican research or teaching institutions have studied it.

Starting once again with primary documentary collections and guides, we must begin with an exemplary work from the prolific Jan de Vos. His catalog of documents from and about Chiapas housed in the Archivo General de Centroamérica in Guatemala City is essential as a starting point for any study of the Chiapan colony. ${ }^{13}$ (De Vos's many other contributions to the history of the jurisdiction fall into other categories and will be discussed later.) Another historian who has emphasized primary documents is André Aubry, who edits the Boletín del Archivo Histórico Diocesano in San Cristóbal de Las Casas. Aubry has published, among other writings, colonial documents from the cathedral collections. ${ }^{14}$

The indefatigable and resourceful Mario Humberto Ruz has added greatly to our knowledge of Chiapas before 1720 by his work on primary sources, accompanied by voluminous commentaries and explanations. One thinks, for example, of Las lenguas de Chiapas colonial, where some of the documents are from later years, and above all of Constituciones Diocesanas del Obispado de Chiapa by Bishop Francisco Núñez de la Vega, edited with enormous care and judicious explication by both Ruz and María del Carmen León Cázares. Also worthy of greater discussion than can be given here is Ruz's edition of the Vocabulario de Lengua Tzeldal Según el Orden de Copanabastla. ${ }^{15}$

Gudrun Lenkersdorf has continued to publish on the very earliest years of the colony, especially the troubled years of the conquest. On p. 280 of her Génesis histórica de Chiapas, there is a bibliography of her work up to the early 1990s. Jan de Vos weighed in on the conquest with a vigorous denunciation of the lack of accuracy and misleading storytelling, plus other critiques, in Antonio de Remesal's famous chronicle. ${ }^{16}$

Because Chiapas was and is overwhelmingly Indian and rural, it is no surprise that much of the scholarship has concentrated on ethnohistory and land tenure. Authors such as Dolores Aramoni Calderón and, once again, Mario Humberto Ruz have written about local groups within Chiapas, and Robert Wasserstrom, in four of the seven chapters of his much-discussed Class and Society in Central Chiapas, studied colonial exploitation and resistance, among other matters, in that subregion. ${ }^{17}$ Perhaps the most comprehensive survey of native ethnohistory is again by Jan de Vos. See, for example, the chapters on the colonial period in Vivir en frontera: La experiencia de los indios de 
Chiapas, one of the many volumes in the outstanding series Historia de los pueblos de México. ${ }^{18}$

Research on the evolution of landholdings in colonial Chiapas has concentrated on the emergence and development of the hacienda. Mario Humberto Ruz has written about the larger landholdings around Comitán, the most ladino area of the highlands outside the city of San Cristóbal. Mari José Amerlinck de Bontempo has devoted at least one essay to the place of the haciendas owned by the omnipresent Dominican order in the province. ${ }^{19}$

Chiapas has had a turbulent history, and the great emphasis in recent writing has been, as a result, on resistance and revolt. Most of these publications discuss the years since independence and annexation, especially recent upheaval since the Zapatista uprising, which began in 1994 and continues. Two significant books, however, have studied these events and their causes from the Spanish invasion to the present. Antonio García de León, in a two-volume study, manipulates little-known material and some shocking photography as well as describing the main events. The collection of essays compiled by Mario H. Ruz and Juan Pedro Viqueira on the same subject is now in its third printing thanks to the surge of interest in Chiapas revolts in Mexico today.

Ruz, once again, with María del Carmen León Cázares and José Alejos García, added yet another study to the tale of centuries-long resistance. Slightly different in emphasis, in that it deals also with elite politics and local communities in Guatemala and Soconusco as well as Chiapas, is the study of an elite uproar in which some black and Indian communities participated. In it María del Carmen León Cázares's slim but important book discusses the scandals and revolt surrounding the ill-starred visita of Francisco Gómez de la Madriz. ${ }^{20}$

On the great revolt of 1712 , somewhat misnamed the Tzeltal Revolt, several noteworthy publications have appeared. Kevin Gosner's Soldiers of the Virgin is the most comprehensive, but the late Severo MartínezPeláez,Juan PedroViqueira, and Richard Patch (whoalso studied eighteenth-century riots elsewhere) have discussed these messianic, widespread events in the highlands. Dolores Aramoni Calderón and I have examined the dramatic but much smaller riot in the town of Tuxtla, 1693, in which the alcalde mayor or Spanish governor of Chiapas was assassinated, among others. The MacLeod and Wasserstrom compilation forecasts that Chiapas will continue to be violent, and that this will encourage historians and journalists, opportunistic or serious, to try to document and understand the origins and evolution of this phenomenon. ${ }^{21}$ 
A subtext of the many studies emphasizing ethnohistory and rebellion has been attempts, similar to the one examined by León Cázares among governmental elites in Guatemala, to analyze elite struggles in Chiapas for political dominance and control of the largely Indian laboring population and its products. Special attention is given to the three leading factions: the Dominican order, the various alcaldes mayores and their entourages, and the creole elites, often represented by the cabildo of San Cristóbal or by ad hoc groups of hacienda owners. ${ }^{22}$

The cacao-rich province of Soconusco, which paid tribute to Moctezuma, was the source of considerable wealth, especially in the sixteenth century. Janine Gasco has published on the archaeology and early colonial history of this province and has few competitors. The late Peter Gerhard in his Southeast Frontier of New Spain discusses the political and jurisdictional geography of Soconusco and many other provinces in what are today Mexico and the nations of Central America. ${ }^{23}$

Research and writing on colonial Guatemala, in many ways the heartland of colonial Central America, is by far the largest single category in this essay. (For convenience, and anachronistically, the alcaldías mayores of San Salvador and Izalcos, today's El Salvador, will be treated as entities separate from Guatemala, although for most of the colonial period they were not.)

Given the volume of work on Guatemala, it is surprising that there is somewhat of a lack of documentary collections and archival guides. René Acuña has published an excellent edition of the Relaciones geográficas del siglo $X V I$ that includes one volume on Guatemala. Little used so far have been the three volumes edited by Juan José Falla, Extractos de escrituras públicas. Special mention must be made of what should develop into a large enterprise. The indefatigable Mario H. Ruz has coordinated the first two volumes of the Memoria eclesial guatemalteca, destined to be a vast annotated collection of documents from the archives of the cathedral in Guatemala City. These first two massive volumes cover episcopal visitas, or tours of inspection, from 1646 to 1715 , and have material on many aspects of native life, quarrels among ecclesiastics, the actions of bishops and other clerics, the relative degrees of poverty and wealth among rural people and villages, cofradias, trading goods by locality, and so on. Of importance as a guide is Gustavo Palma Murga's edition of the Indice general del archivo del extinguido Juzgado Privativo de Tierras. Other archival guides include those by Pedro López Gómez, Jorge Luján Muñoz, and Lawrence Feldman. ${ }^{24}$

There are several general studies of Guatemalan history rang- 
ing from mid to late in the colonial period to beyond it. Worthy of mention are the books by David McCreery, Francisco de Solano and Miles Wortman. ${ }^{25}$ The one indispensable collection, edited by the prolific dean of Guatemalan history studies Jorge Luján Muñoz, is the six volumes entitled Historia general de Guatemala. This enormous and invaluable group effort, very comprehensively summing up the scholarship of the late twentieth century, is an essential point of departure for serious students of Guatemalan history. ${ }^{26}$

Demography, especially the history of native population decline before the early or mid seventeenth century, has continued to interest scholars of the region. The entries and commentaries in the previously discussed bibliography by Lovell and Lutz make an all too brief mention here of a large body of work somewhat excusable, but any survey should mention as representative the writings, not only of the above two authors, individually and together, but also of Robert Carmack, Genoveva Enríquez Macías, Jorge Luján Muñoz, once again, Thomas T. Veblen, and Elías Zamora Acosta. ${ }^{27}$

Another field that, while far behind demographic studies in volume, is growing rapidly in very recent years, is the reproduction, with related commentary and annotation, of texts in native languages, especially the lingua franca, Nahuatl. Florine G. L. Asselbergs has written what is perhaps the most comprehensive study of one of these manuscripts in her fascinating book, Conquered Conquistadors: The Lienzo de Quauhquechollan, a Nahua Vision of the Conquest of Guatemala, a true piece of historical detective work..$^{28}$ Robert Carmack and James L. Mondloch have continued their work in Totonicapán on such documents with their edited book, El titulo de Yax; and an important series of letters of complaint in Nahuatl, sent to the Crown by native leaders from villages near Santiago de Guatemala, now Antigua, dating from c. 1572, have been transcribed and placed in context by Karen Dakin and Christopher Lutz, Nuestro pesar, nuestra aflicción, tunetuliniliz, tucucuca: Memorias en lengua náhuatl enviadas a Felipe II por indigenas del Valle de Guatemala hacia $1572 .^{29}$ With his customary thoroughness and care, René Acuña took a decade to transcribe, introduce, and annotate Fray Thomás Coto's massive colonial Vocabulario of the Cakchiquel language. On the other hand, the following book entitled Mesoamerican Voices: Native-Language Writings from Colonial Mexico, Oaxaca, Yucatan, and Guatemala, edited by Matthew Restall, Lisa Sousa, and Kevin Terraciano, is somewhat disappointing to students of Guatemala. It contains only two documents from the region, neither of them printed for the first time. Robert Hill and Laura Matthew also have published studies of native language documents, and plan more. ${ }^{30}$ 
Labor, the encomienda, and the repartimiento have continued to attract some scholars. Already an oft-quoted classic is the outstanding work of the late William L. Sherman. An equally thorough but shorter work is the book on the early encomienda by Wendy Kramer. Others who have worked in this subfield include Horacio Cabezas, Jorge Luján Muñoz, Julio César Pinto Soria, and Salvador Rodríguez Becerra. $^{31}$

The greatest increase in Guatemalan colonial historiography, however, has been in local or regional studies. Such is the number of these studies, and the new findings in some of them, that previous wider generalizations must now be questioned. As a group, in fact, these writings create the need for a group of historians to attempt some new and larger synthesis. Perhaps the most interesting aspect of regional studies has been the surge in urban research, especially on Santiago, where the work of Christopher Lutz has been outstanding. ${ }^{32}$

Verapaz was a separate bishopric and an almost exclusive preserve of the Dominican order for most of the years that concern us here. Its colonial history has been well examined by several French scholars such as Michel Bertrand and the late Nicole Percheron in several publications. Cofradias, production and trade, population decline, Indian life, Dominican conversion methods and domination, and local resistance all receive attention. Larry Feldman has provided a useful statistical account. ${ }^{33}$

The Spanish invasions of the Peten and adjacent areas from Verapaz have not received the detailed analysis that Grant Jones in his two books, and others, have provided for the entradas from Yucatan and Campeche. But Larry Feldman has gathered together a wide selection of primary documents on such attempts, and Stephen Webre in his research on the regime and difficulties of President Jacinto de Barrios Leal has made an interesting start, as has Jan de Vos, once again, in his studies of the Lacandon. ${ }^{34}$

Some of the most notable of the Guatemalan regional and local studies, listed alphabetically by author, have been Barbara Borg (Sacatepéquez) and Anne Collins (Jacaltenango), both dissertations from the 1980s; Robert Hill and John Monaghan (Sacapulas); Oscar H. Horst (San Juan Ostuncalco); George Lovell (Cuchumatanes); Jorge Luján Muñoz (Valle or Corregimiento of Guatemala, plus his studies of Petapa and of new ladino villas); Sandra Orellana (Tzutujiles); Jean Piel (Sacabajá-a village study that reaches to 1970); Thomas T. Veblen (Totonicapán) and Elías Zamora (Tierras Altas, perhaps too great an area to be considered a local study). ${ }^{35}$ 
Special mention should be given to the recent book by Isabel Rodas Núñez, De españoles a ladinos: Cambio social y relaciones de parentesco en el Altiplano central colonial guatemalteco. The title is misleading because what we have here is a study of the town of Patzicía, but by use of anthropological insights, attention to family relations and reconstruction, intelligent manipulations of statistical data, and the study of the impact of immigration of non-natives to the town, she has produced a model study that could be replicated with profit elsewhere. $^{36}$

Church history has produced several books of note, perhaps the most outstanding being the book and essays by the late Adriaan Cornelis van Oss. Examinations of the work and personalities of the great chroniclers, group and individual biographies, especially for some reason the lives of colonial bishops-perhaps as a group they tended to leave more detailed documentation behind them-and the study of seaports and defense against pirates and smugglers have all drawn attention. ${ }^{37}$

The two alcaldias mayores of San Salvador and Izalcos (Sonsonate) are somewhat of a historical paradox. In the first two colonial centuries, this region (today approximately the republic of El Salvador), while not the main center of power in Central America (that was Santiago), was its economic heartland, especially during the cacao boom of the sixteenth century and the indigo boom of the late seventeenth and most of the eighteenth centuries. Yet, writing lags on this place and era, perhaps more than on any other part of Central America. ${ }^{38}$

Lack of archival guides and the publication of primary documents are indicative of this curious situation. The Códice Sonsonate is not a codex, and is at once charming and unsatisfying. It is an old-fashioned "tales from long ago" but does have the advantage of including excerpts from some primary documents. ${ }^{39}$ Also published in this category were several editions, of which the Mexican one is perhaps the best, of the "Carta-Relación" by the oidor Diego García de Palacios during a visita to San Salvador in the 1570s. This edition also includes the instructions on how to "visit" and assess tribute, the well-known "Relación y forma."

A great addition to Salvadoran historiography has been the Biblioteca de Historia Salvadoreña, which, if information here is correct, has so far published sixteen volumes, many of them previously outof-print works by important Salvadoran historians, leaders from the past. Included are three works by Jorge Lardé y Larín and the pioneering demographic study by Rodolfo Barón Castro. ${ }^{41}$ Of equal importance is the publication in the same series of two modern studies. 
Los tlaxcaltecos en Centro América by Pedro Escalante Arce studies the Mexican auxiliaries who arrived in Central America with the invading Spaniards of the sixteenth century. While the text concentrates on San Salvador, it also covers other areas. ${ }^{42}$

Of great importance for the economic history of the region is José Antonio Fernández, Pintando el mundo de azul. While not ignoring the preceding years, the author concentrates on the years 1750-1810, outside our present chronological limits but the era of the indigo dye boom that dominated the Central American economy until the late eighteenth century. (The book is an expanded version of an English language doctoral dissertation.) The late Manuel Rubio Sánchez, another prolific author and transcriber of primary documents, also published on Salvadoran indigo production. ${ }^{43}$ One hopes that the Biblioteca de Historia Salvadoreña will continue its fine work on building up the historical bibliography of the province and republic.

William R. Fowler, an archaeologist and anthropologist, interested above all in the Pipiles of San Salvador, Izalcos, and elsewhere, is the most important writer and investigator on the culture and demography of that linguistic group before and after the Spanish conquest. His many publications lay the foundation for later colonial studies, and some contain transcriptions of primary documents. ${ }^{44}$

Another scholar who has made a pioneering contribution to the history of the area is Santiago Montes Mozo, whose twin volumes on the guachival, or unofficial or folk confraternity, are one of the very few studies of this institution, certainly for San Salvador. Depending heavily on the episcopal visit and reports of Bishop Pedro Cortés y Larraz, also late in the colonial period for our purposes, the volumes remain of value for earlier years and have opened a door to understanding an intense cultural life not usually found in official documents. ${ }^{45}$

A good augury for the future of Salvadoran history is the recent book compiled by Ana Margarita Gómez and Sajid Alfredo Herrera, Mestizaje, poder $y$ sociedad, a collection of eight essays on the colonial period in the two districts. One of the more intriguing findings in several of these essays is the considerable demographic, cultural, and economic weight, much ignored until recently, of the black and mulatto populations, notably in El Salvador, but also along the Pacific coast and hinterland of Guatemala. Honduran historians, as we shall see, are discussing similar discoveries. Most of the book studies the eighteenth century, yet again, but the youth of these essayists, the variety of the subject matter, and the thoroughness and skill of most of the research all suggest that the lag in Salvadoran colonial history may soon be a thing of the past. ${ }^{46}$ 
Reviewing more than thirty years of intellectual effort in colonial history in a large and varied region is an opportunity to see tendencies and fashions that one had not previously discerned, involved as we all are in our own research corners. It was no surprise to find that work on colonial Chiapas, and indeed the modern period too, deals heavily with questions of interethnic relations, exploitation, and revolt. This is fully understandable, but some emphases elsewhere seem more idiosyncratic, perhaps more related to the personal curiosity of small numbers of people, and seem less tied to what appear to be dominant historical phenomena.

The quantity of publications on colonial Honduras is substantial and growing, and some of the subject matter is not surprising. Linda Newson's writings on native population decline and on the mining industry are well known. More recent (1998) is the excellent study by Luis Pedro Taracena Arriola on politics and mining in the alcaldia mayor of Tegucigalpa in the eighteenth century. The productive Mario Felipe Martinez also has written about the same city and its surroundings. The labor repartimientos for the mines have drawn the attention of María de los Angeles Chaverri, and she has reported her findings in at least two of the Central American history congresses. ${ }^{47}$

More surprising are the several useful documentary collections. The aforementioned Mario Felipe Martínez has edited two collections of colonial documents. Héctor M. Leyva has edited another. More surprising still have been the concentration on the colonial church, and especially the work on native peoples and their encounter with Mercedarian missionaries. Two histories cover both the colonial and national periods. José Reina Valenzuela's Historia eclesiástica de Honduras in two volumes was followed a year later (1991) by Marcos Carías's similar work. Anne C. Collins wrote on the activities of the Mercedarians in western Honduras, and Anne Chapman has brought together much of her work on the Lencas in two volumes. ${ }^{48}$

Mesoamérica devoted number 42 (2001) to the history of Honduras, with two of the essays discussing the place of Honduras in early sixteenth-century Caribbean commerce and the presence of a large African slave population in the country from the earliest days of the colony. A footnote on p. xi lists many of the young historians of the nation, and laments how little they are known outside Honduras. ${ }^{49}$

More surprising still is the number of studies on a truly marginal area, if it belongs to any work of Spanish colonial Central America at all. (The Caribbean shore known as Mosquitia was and is divided between Honduras and Nicaragua.) On the Mosquito, or Miskito, Coast, the bibliography is extensive but poorly known by this commentator. Craig Dozier, Jesús María García Añoveros, Robert A. Nay- 
lor, Barbara Potthast, Germán Romero Vargas, and Douglas Thompson all have published on various aspects of the history of the shore, early and modern, and of the English presence there..$^{50}$

Perhaps the most influential book on colonial Nicaragua since the 1970s has been the one by the aforementioned Germán Romero Vargas, Las estructuras sociales de Nicaragua en el siglo XVIII (1988). Although late for our concerns and chronologically barely overlapping the first two hundred years, it imposes a thorough and elaborate model for an understanding of eighteenth-century society in the province and opens many avenues for research. ${ }^{51}$ Two themes have been popular in early colonial studies of Nicaragua. One has been the sixteenth-century native population decline and the related export of Indian slaves to Panama, probably to Isla Margarita, and to Peru. Linda Newson, David Radell, and Dan Stanislawski all have published on this topic, and while there is debate about totals and causes of this and other population catastrophes, all agree that it was severe. ${ }^{52}$

The other topic, given Nicaragua's lowland isthmian geography, has been the San Juan River, its use for trade, its defense, and its prospects as a trans-isthmian route to the Pacific. Jaime Incer and, once more, David Radell, this time with the collaboration of the renowned James Parsons, have both explored these matters. ${ }^{53}$

For quantity and quality, Costa Rica may rival Guatemala in publications and research on the first two hundred years of the colonial period. The late Carlos Meléndez Chaverri continued his work on the conquest, the conquistadors, and land tenure into the 1990 s. $^{54}$ Victor Hugo Acuña, Héctor Pérez Brignoli, and Juan Carlos Solórzano Fonseca have written and continue to write on external commerce, population, and local products. Phillip MacLeod and Carlos Rosés have studied the brief cacao boom on the Caribbean coast around Matina, and María Eugenia Brenes Castillo is one of several scholars who look at the contraband trade with the English and other interlopers from the same port. ${ }^{55}$ As in other parts of Central America, subjects such as the early encomienda, researched by Claudia Quirós Vargas; colonial revolts, many on the Talamancan periphery, studied by Claudio Barrantes Cartín and others; subsistence crises, worked on by José Antonio Fernández Molina, whom we have already met because of his work on San Salvador; and regional studies such as the one by Luis Fernando Sibajá on Nicoya, are all worth noting. ${ }^{56}$

A truly pioneering work, with some attention to the early period, is Ana Paulina Malavassi Aguilar's study of leprosy in Costa Rica in the late colonial and early national period. (There is a résumé of her work in Mesoamérica. $)^{57}$ 
Panama, often considered not part of Central America, has tended to ignore the early colonial period because of its troubled national history and the dominance for so many years of the Panama Canal question. As already mentioned, this is paradoxical because the isthmus was, of course, a central part of the colonial commercial system and its famous trajin a lifeline of the empire. As a result, what literature we have often concentrates on such matters as local and imperial defense, economy and trade, and pirate attacks seeking to grab the riches crossing the isthmus. Alfredo Castillero Calvo, who began to work on these subjects before 1973, has continued to write about them until now. María del Carmen Mena García works along similar lines, especially for the sixteenth century. Enriqueta Vila Vilar has worked on the long-neglected Portobelo fairs, and Christopher Ward, in his 1993 book, Imperial Panama, while discussing many matters, concentrates on trade and defensive structures. ${ }^{58}$

Other work continues. The economic geographer Omar Jáen Suárez has studied population trends up through the twentieth century and also has given us important regional studies. ${ }^{59}$ Carol F. Jopling edited an important volume, much of it based on documentation from the Archive of the Indies, on Indians and blacks in the sixteenth and seventeenth centuries. ${ }^{60}$ The inappropriately named journal Lotería continues to publish serious essays on Panamanian history and culture, some of them on the colonial period.

Our journey through these former provinces of the empire and their historiography has yet to reach some traditional themes, still enthusiastically cultivated. After a brief glance at them, we will turn to some of the debates that engage some members of the profession.

Imperial defense, as we have just seen, has been a central part of the limited Panamanian colonial historiography. But the history of fortifications, armaments, and ports also has been a continuing theme in all of Central American history, from Tabasco and Belize all the way to the Costa Rican border with Panama. Some of the publications attracting notice over the years have included the following. There is a book by Víctor Cruz Reyes et al. on the fort of San Fernando de Omoa; many essays and books by Manuel Rubio Sánchez on Central American ports and their defenses; and a survey by Juan Manuel Zapatero on forts in general. ${ }^{61}$

Another traditional historiography has concentrated for many years on the seismic and volcanic histories of this geologically unstable region. Again, the following works are representative rather than a complete bibliography. Among the many works of Lawrence $\mathrm{H}$. Feldman is one on earthquakes and eruptions in Guatemala. Cleto 
González Víquez, who has been writing for many years, studied the same phenomena in Costa Rica. What one misses so far is a wellrounded history such as the short attempt by André Saint-Lu of the social and economic consequences of these events. ${ }^{62}$

We now turn to three fields of inquiry that either have radically changed our thinking on specific subjects or have caused interesting debate about the basic nature of economics and power during the first two hundred years of the Central American colonial period.

The first topic is African presence and demographic strength. While it is generally recognized that Panama imported slaves from Curaçao and elsewhere to replace its vanished Indian population, and that the population of the Caribbean coast from Belize to Panama had a large black component during the colonial centuries, and received many more people from the Caribbean islands during the nineteenth and twentieth centuries as the Canal, railroads, and plantations sought tropical labor, it has been received knowledge that that was all. The interiors, highlands, and Pacific shores, it was assumed, were predominantly Indian and ladino in ethnic and cultural origins. Many of this writer's generation, including this writer himself, simply mentioned in passing the African presence in the areas more or less firmly under Spanish control.

There were some pioneering studies. Thomas Fiehrer, back in 1979, discussed Negro slaves and freedmen in Guatemala in The Journal of Negro History. Michael Olien (1980) wrote about the black population of Costa Rica. ${ }^{63}$ Now, studies based on marriage records and other demographic statistics are radically changing this sensitive and, to some, alarming picture. Paul T. Lokken, in a dissertation and subsequent articles, has demonstrated that the black population of the Pacific coast of Guatemala in the seventeenth century was large, often second only to the Indian groups in demographic strength, and in a few places an outright majority. Christopher Lutz, writing about the city of Santiago de Guatemala, shows that the black and mulatto population was a significant proportion of the inhabitants. Robinson Herrera in a recent book finds that this was the case even in the sixteenth century. The book on San Salvador already mentioned shows that in these two provinces the black population was second only to the indigenous one and predominated, again, in a few places. ${ }^{64}$

Obviously, such findings should lead to considerable rewriting of demographic, ethnic, and cultural history. Another question of great interest, sure to provoke some debate, is what happened to these black populations, and what periodization and factors should 
be used to establish not only their demographic size but also their "amalgamation"?65

Yet another thriving avenue of research is into the nature of elite power and competition. One of the mainstays of these studies is the membership of the colonial ayuntamiento of the capital city and the seat of the audiencia. Should we consider such membership as a sign of power or merely a kind of status and prestige? Stephen Webre and David Jickling have studied these memberships, and Jorge Luján Muñoz and others, both in the corregimiento del valle and over the question of monopolies or eighteenth-century estancos, show that in struggles between the cabildo and the audiencia the local elites could hold their own in matters of concern to them. ${ }^{66}$

Again it is clear, as our ideas of the power of these elites changeand these ideas will be different depending on where and when we place our studies, not only in Santiago but also in many of the lesser cities-we will have to rearrange some ideas and how we view the effectiveness, authority, and even legitimacy claims of the regime. Richmond Brown in his biography of the rich eighteenth-century businessman and merchant Juan de Aycinena, believes that Aycinena was able to use the system far more than it could use him. ${ }^{67}$

Our last debate concerns the relative importance of colonial Central America's trade and exchanges within the region, with other Spanish American colonies, and with the wider Atlantic world. Miles Wortman began the debate by asserting that the seventeenth-century depression, a central part of Spanish Central America, was less severe than had been argued or indeed did not exist at all. To make this point, he emphasized interregional trade, especially with Mexico, Havana, and Peru. More recently, Gustavo Palma Murga has made similar claims. ${ }^{68}$

The next writer to address this question was the late Adriaan C. van Oss. One of the main points in his Catholic Colonialism, a study of eighteenth-century priests and parishes in Guatemala, was that much of the colony lived in a state of economic and perhaps political autarchy. He reinforced this thesis in an essay in Mesoamérica that same year. ${ }^{69}$

More recently, we have two books of first importance, Christopher Lutz's study of the city of Santiago, which he paints as a bustling center, has many of the poor living busy if marginally criminal existences by manipulating commercial and social aspects of the system. In short, the city had its own somewhat independent dynamism, in its way quite apart from the larger empire. Robinson Herrera's recent book goes even further. He finds that even sixteenth-century Santiago dominated and interacted with a large catchment area, and 
active traders and business people of both genders and all classes and ethnicities conducted their exchanges intensely and often successfully, even with faraway Mexico City. ${ }^{70}$

This reader of these studies is partly convinced. What may be required is a new synthesis, which attempts to link international trade, interregional and local trade, urban commerce, and rural selfsufficiency into an interdependent or at least more complex model.

Why only partially convinced? First of all, the model of the selfsufficient peasant is dubious in the extreme. Do such people exist in sedentary societies, or is the peasant in some ways a creation of cities, their markets, and the elites there? Let us also consider the cultural aspirations and the history of sixteenth- and seventeenthcentury Central American elites. By their own statements, they sought endlessly for a major export commodity or commodities that could bring them wealth, and when such opportunities came, or appeared to present themselves, they were eager to reorganize land and labor as drastically as conditions allowed, with very little debate. Only when such hoped-for trades declined or failed to appear would they turn to more banal activities such as extorting surpluses from native peoples or abusing them with unequal "trading." That their late-sixteenth-century and seventeenth-century businesses were for them a second choice, a reluctant alternative position, can best be demonstrated by considering the eager alacrity that seized them when larger prospects appeared, even those to be won via the little studied contraband trades with Spain's enemies. Aycinena, admired enormously for his success, not only sought vertical integration of his local and interprovincial affairs, from the smallest Indian producer to his partners and agents in the provinces, but also sought wherever possible to establish international links and representatives for his bigger aspirations. His peers saw this and tried to emulate him. It also appears somewhat ingenuous to consider the poor-many, especially women, sunk in poverty and desperately scratching a living by avoiding or paying off those who enforced the strictures of the law-as entrepreneurs in any developmental or healthy sense. And as for the autarchic Indians and priests of the countryside, bishops, local governors, and the aspiring Aycinenas of the cities and haciendas co-opted them, in spite of the "weapons of the weak," as needed.

There are many fields of inquiry today, which draw the attention of researchers outside Central America but find little support among historians of the region. Studies of the role of gender, for example, are very few for the first two colonial centuries, and similar studies of medicine or the environment have been all but ignored. 
Nor have historians of Central America yielded much to the charms of structuralism or postmodernism, and the new cultural history has produced few disciples, for better or worse. Whether these are deliberate choices or some sort of cultural lag, or both, is difficult to discern, and debates on their utility or attractiveness have hardly begun.

There are, however, many encouraging signs. The history of the first two centuries of Spanish rule in Central America started the 1970s far behind centers such as Mexico or Peru in quantity and complexity, but the advances of the last thirty years and more have been impressive. There had been some great pioneers within Central America itself, some of them wealthy enough to indulge in such uneconomic activity as writing history; others were so enamored of the subject that they ignored earning a living or the consequences. Many of them, appropriately for their times, wrote traditional narrative histories or accounts of dramatic events and leading personalities. The próceres and heroes of the immediate post-independence struggles were especially revered.

The new generations are more numerous, professional, and eclectic. They are skeptical about evidence but use much more of it, especially archival documentation. While exchanges of views, information, and publications are still frustrating at times because of difficult economic and political conditions, the volume of history being produced and the enthusiasm and combativeness of so many hard-working and innovative historians today give us considerable optimism for the future.

\section{Notes}

1. Juan de Mariana (1536-1624), an inheritor of medieval ideas about the contractual relationship between sovereigns and their people, advocated tyrranicide, among other controversial writings, in his De rege et Regis Institutione. Appropriate excerpts in Spanish translation can be found in Mariana, La tiranía y los derechos del pueblo (Mexico City: Secretaría de Educación Pública, 1948).

2. For Simpson's essay "Mexico's Forgotten Century," see the main bibliography of this book.

3. My thanks to Christopher Lutz for his great help with bibliographical information. Specifically, I wish to thank Héctor Concohá, Beatriz Lewin, and, again, Christopher Lutz for their help in locating theses in the Universidad de San Carlos and Universidad del Valle libraries. Some can also be found in the Biblioteca Nacional de Guatemala. Héctor Pérez Brignoli gave me the Web site for Costa Rican theses, as follows: http:// 
cuuics.fcs.ucr.ac.cr/info/busquedas/buscarAutor.php. I have read only a few, and some also have been published.

4. One brave attempt, now much out of date, is that of Sidney David Markman, ed. and comp., Colonial Central America: A Bibliography (Tempe: Center for Latin American Studies, Arizona State University, 1977). Markman emphasized art and architecture, as one would expect. Another useful bibliography is Gloria Alvarez and Hamlet García, Fuentes históricas de Centro América de la época colonial (Managua: Biblioteca del Instituto Histórico Centroamericano, 1994). Consult also Edelberto Torres Rivas and María Eugenia Gallardo, Para entender Centroamérica: Resumen bibliográfico, 1960-84 (San José: Instituto Centroamericano de Documentación e Integración Social, 1985). One estimate claims that 80 percent of all writing on Central America has been published since 1975.

5. Edelberto Torres Rivas, ed., Historia general de Centroamérica, 6 vols. (Madrid: Comunidades Europeas/FLACSO, 1993-1997). Vol. 2, El régimen colonial edited by Julio César Pinto Soria, is the appropriate one here.

6. Carolyn Hall and Héctor Pérez Brignoli (John V. Cotter, cartographer), Historical Atlas of Central America (Norman: University of Oklahoma Press, 2003).

7. Ernesto Chinchilla Aguilar, Blasones y heredades: Historia de Centroamérica, II (Guatemala City: J. de Pineda Ibarra, 1975); Elizabeth Fonseca Corrales, Centroamérica: Su historia (San José: FLACSO/EDUCA, 1996); Rodolfo Pastor, Historia de Centroamérica (Mexico City: El Colegio de México, 1988); Héctor Pérez Brignoli, Breve historia de Centroamérica (Madrid: Alianza Editorial, 1985); and Ralph Lee Woodward, Central America: $\mathrm{A} \mathrm{Na}$ tion Divided (New York: Oxford University Press, 1985).

8. An exception is Patrick S. Werner, who has mined the Recopilacion de leyes de Indias, the Colección Somoza, and this Monumenta in, for example, his Ethnohistory of Early Colonial Nicaragua. Demography and Encomiendas of the Indian Communities (Albany: State University of New York, Institute of Mesoamerican Studies, 2000) and in his presentations to the Congresos of Central American historians.

9. The Libro de los pareceres is edited and commented upon by Carlos Alfonso Alvarez-Lobos Villatoro and Ricardo Toledo Palomo (Guatemala City: Academia de Geografía e Historia de Guatemala, Biblioteca "Goathemala," 32, 1996). The Cartas de cabildo, 2 vols., are edited by Javier Ortiz de la Tabla, Bibiano Torres Ramírez, and Enriqueta Vila Vilar (Seville: Escuela de Estudios Hispano-Americanos, 1984-1986). Consult also, Beatriz Suñe Blanco, La documentación del cabildo secular de Guatemala (siglo XVI): Estudio diplomático y valor etnográfico (Seville: Universidad de Sevilla, 1984).

10. See my comments, especially on Markman's bibliography, in note 4 .

11. But, see Marcela Camargo R. and Yolanda Marco Serra, comps., Memoria del VI Congreso Centroamericano de Historia, Panamá, 22-26.7.2002 (Panama City: Facultad de Humanidades, Departamento de Historia, 
2005) for thirty of the many papers delivered there. The session on cultural history from the 7th congress in Tegucigalpa contained papers on Costa Rica, El Salvador, Guatemala, Honduras, Nicaragua, and Panama of varying length and complexity. All were published in Diálogos: Revista Electrónica de Historia (San José), 6, no. 2 (August 2005-February 2006). The bibliographies are comprehensive, huge, and of great value. Especially noteworthy is José Edgardo Cal Montoya, "La Historia Cultural en Guatemala: Un itinerario para recoger. Reflexiones Historiográficas," pp. 83-97. The footnotes themselves are exceptionally instructive.

12. W. George Lovell and Christopher H. Lutz, Demography and Empire: A Guide to the Population History of Spanish Central America, 1500-1821 (Boulder: Westview Press, Dellplain Latin American Studies, No. 33, 1995). A Spanish edition, Demografia e Imperio, appeared in 2000 (Guatemala City: Editorial Universitario). So far we have no extensive Daniel Defoe-like contemporary accounts of living in an epidemic, such as are found in abundance in Western Europe. One such record is James S. Amelang, ed. and trans., A Journal of the Plague Year: The Diary of the Barcelona Tanner Miquel Parets, 1651 (New York: Oxford University Press, 1991). Pages 91-105 contain a listing of more than eighty Western European eyewitness chronicles, all before 1700 .

13. Jan de Vos, Catálogo de los documentos históricos que se conservan en el fondo llamado "Provincia de Chiapas" del Archivo General de Centroamérica, Guatemala, 2 vols. in 3 (San Cristóbal de Las Casas, Chiapas: Centro de Estudios Indígenas /UNACH, 1985).

14. Worth finding are any of the volumes of Boletin del Archivo Histórico Diocesano, published in San Cristóbal de Las Casas, intermittently since 1983. The title varies.

15. Mario Humberto Ruz, ed., Las lenguas del Chiapas colonial, Manuscritos en la Biblioteca Nacional de Paris (Mexico City: UNAM, 1989); Francisco Núñez de la Vega, Constituciones diocesanas del obispado de Chiapa, María del Carmen León Cázares and Mario Humberto Ruz, eds. (Mexico City: UNAM, 1988); and Fr. Domingo de Ara, Vocabulario de lengua tzeldal seguin el orden de Copanabastle, Mario Humberto Ruz, ed. (Mexico City: UNAM, 1986), which brings us to Ruz's important book on the life, decline, and disappearance of a Chiapas town, Copanaguastla en un espejo: Un pueblo tzeltal en el Virreinato (San Cristóbal de Las Casas, Chiapas: Centro de Estudios Indígenas, UNACH, 1985).

16. Gudrun Lenkersdorf, Génesis histórico de Chiapas, 1522-1532: El conflicto entre Portocarrero y Mazariegos (Mexico City: UNAM, 1993). For some of her other writing on the early colony, see p. 280. See also her Repúblicas de indios. Pueblos mayas en Chiapas, siglo XVI (Mexico City: UNAM, 2001). For Jan de Vos on the unreliability of Antonio de Remesal, see his Los enredos de Remesal: Ensayo sobre la conquista de Chiapas (Mexico City: Consejo Nacional para la Cultura y las Artes, 1992).

17. Dolores Aramoni Calderón, Los refugios de lo sagrado: Religiosidad, conflicto y resistencia entre los zoques de Chiapas (Mexico City: Consejo Nacio- 
nal para la Cultura y las Artes, 1992); María del Carmen León Cázares, Mario Humberto Ruz, and José Alejos García, Del Katún al siglo: Tiempos de colonialismo y resistencia entre los mayas (Mexico City: Consejo Nacional para la Cultura y las Artes, 1992) - the first 162 pages discuss colonial times; and Robert Wasserstrom, Class and Society in Central Chiapas (Berkeley: University of California Press, 1983).

18. Jan de Vos, Vivir en frontera: La experiencia de los indios de Chiapas (Mexico City: CIESAS, 1994).

19. Mari José Amerlinck de Bontempo, "Conquista espiritual y económica: La formación de haciendas de frailes dominicos en Chiapas," Mesoamérica 20 (1990), 215-229; Mario Humberto Ruz, Savia india, floración ladina: Apuntes para una historia de las fincas comitecas (siglos XVIII y XIX) (Mexico City: Consejo Nacional para la Cultura y las Artes, 1992)-the first ninety pages discuss the period up to 1720 .

20. Antonio García de León, Resistencia y utopía: Memorial de agravios y crónica de revueltas y profecías acaecidas en la Provincia de Chiapas durante los últimos quinientos años de su historia, 2 vols. (Mexico City: Ediciones Era, 1985); only vol. 1 deals with colonial material. Also consult Juan Pedro Viqueira and Mario Humberto Ruz, eds., Chiapas: Los rumbos de otra historia, 3rd printing (Mexico City: CIESAS, 2002). The essays by Murdo J. MacLeod and Juan Pedro Viqueira examine specific revolts before 1720 . See also María del Carmen León Cázares, Un levantamiento en nombre del Rey Nuestro Señor: Testimonios indígenas relacionados con el visitador Francisco Gómez de Lamadriz (Mexico City: UNAM, 1988). For Del Katún al siglo, see note 17 above.

21. Kevin Gosner, Soldiers of the Virgin: The Moral Economy of a Colonial Mayan Rebellion (Tucson: University of Arizona Press, 1992); Juan Pedro Viqueira Albán, Indios rebeldes e idólatras: Dos ensayos históricos sobre la rebelión india de Cancuc, Chiapas, acaecida en el año 1712 (Mexico City: CIESAS, 1997). Viqueira also has written a small, charming, and fanciful book on this revolt, Maria de la Candelaria, india natural de Cancuc (Mexico City: Fondo de Cultura Económica, 1993), and a somewhat different interpretation of its origins in "Tributo y sociedad en Chiapas, 1680-1721," Historia Mexicana 44, no. 2 (1994), 237-267. Also worth adding is André Saint-Lu, "El poder colonial y la iglesia frente a la sublevación de los indígenas zendales de Chiapas en 1712," Mesoamérica 12 (1986), 23-33. For the Tuxtla riot, we have Aramoni Calderón in her Los refugios, and Murdo J. MacLeod, "Motines y cambios en las formas de control económico y político: Los acontecimientos de Tuxtla, 1693," Mesoamérica 28 (1994), 231-251. For other works that include different uprisings, see Severo Martínez Peláez, Motines de indios (Guatemala City: Ediciones en Marcha, 1991), and Robert W. Patch, Maya Revolt and Revolution in the Eighteenth Century (Armonk, N.Y.: M. E. Sharpe, 2002). The forecast is in Murdo J. MacLeod and Robert Wasserstrom, eds., Spaniards and Indians in Southeastern Mesoamerica: Essays on the History of Ethnic Relations (Lincoln: University of Nebraska Press, 1983), xvi.

22. Martha Ilia Nájera Coronado, La formación de la oligarquía criolla en Ciudad Real de Chiapas: El caso Ortés de Velasco (Mexico City: UNAM, 1993); 
Murdo J. MacLeod, "La espada de la iglesia: Excomunión y la evolución de la lucha por el control político y económico en Chiapas colonial, 15451700," Mesoamérica 20 (1990), 199-213; Milagros Ciudad Suárez, Los dominicos: Un grupo de poder en Chiapas y Guatemala, siglos XVI y XVII (Seville: Escuela de Estudios Hispano-Americanos, 1996); and Nélida Bonaccorsi, El trabajo obligatorio indigena en Chiapas, siglo XVI: Los altos y Soconusco (Mexico City: UNAM, 1990).

23. Janine Gasco, "The Colonial Economy in the Province of Soconusco," and "Economic History of Ocelocalco, a Colonial Soconusco Town," both in Barbara Voorhies, ed., Ancient Trade and Tribute: Economies of the Soconusco Region of Mesoamerica (Salt Lake City: University of Utah Press, 1989), 287-303 and 304-325. More recent is her "Socioeconomic Change within Native Society in Colonial Soconusco," in J. Daniel Rogers and Samuel L. Wilson, eds., Ethnohistory and Archaeology. Approaches to Postcontact Changes in the Americas (New York: Plenum Press, 1993), 163180. See also Peter Gerhard, The Southeast Frontier of New Spain (Princeton: Princeton University Press, 1979), 165-172.

24. René Acuña, ed., Relaciones geográficas del siglo XVI: Guatemala (Mexico City: UNAM, 1982); Gustavo Palma Murga, ed., Indice general del archivo del extinguido Juzgado Privativo de Tierras depositado en la Escribanía de Cámara del Supremo Gobierno de la República de Guatemala: Segunda Parte, que comprende el índice alfabético general (Mexico City: CIESAS, 1991); Pedro López Gómez, El Archivo General de Centroamérica (Ciudad Guatemala) Informe (Madrid: ANABAD, 1991); Jorge Luján Muñoz, Guia del Archivo General de Centro América (Guatemala City: Ministerio de Educación, 1982); Juan José Falla, ed., Extractos de escrituras públicas. Archivo General de Centroamérica, 3 vols. (Guatemala City: Museo Popol Vuh de la Universidad Francisco Marroquín, 1994)-the same editor recently published vol. 4 (2006), but I have not seen it yet; and Mario Humberto Ruz, coord., Memoria eclesial guatemalteca, visitas pastorales, 2 vols. (Mexico City: UNAM, 2002).

25. David McCreery, Rural Guatemala, 1760-1940 (Stanford: Stanford University Press, 1994); Francisco de Solano, Tierra y sociedad en el reino de Guatemala (Guatemala City: Editorial Universitaria, 1979), which also goes beyond the early eighteenth century; and Miles L. Wortman, Government and Society in Central America, 1680-1840 (New York: Columbia University Press, 1982).

26. Jorge Luján Muñoz, general editor, Historia general de Guatemala, 6 vols. (Guatemala City: Asociación de Amigos del País, 1993-1996). Vol. 2, edited by Ernesto Chinchilla Aguilar, and some of vol. 3, edited by Cristina Zilbermann de Luján, are of interest to this essay.

27. Robert M. Carmack, The Quiché Mayas of Utatlán: The Evolution of a Highland Guatemala Kingdom (Norman: University of Oklahoma Press, 1981). See also Robert M. Carmack, John D. Early, and Christopher H. Lutz, eds., The Historical Demography of Highland Guatemala (Albany: State University of New York, Institute for Mesoamerican Studies, 1982); Genove- 
va Enríquez Macías, "Nuevos documentos para la demografía histórica de la Audiencia de Guatemala a finales del siglo XVII," Mesoamérica 17 (1989), 121-183; Jorge Luján Muñoz, "Cambios en la estructura familiar de los indígenas pokomames de Petapa (Guatemala) en la primera mitad del siglo XVI," Mesoamérica 10 (1985), 355-369; Thomas T. Veblen, "Native Population Decline in Totonicapán, Guatemala," in Carmack, Early, and Lutz, The Historical Demography, 81-102; and Elías Zamora Acosta, Los mayas de las tierras altas en el siglo XVI: Tradición y cambio en Guatemala (Seville: Diputación Provincial de Sevilla, 1985).

28. Florine G. L. Asselbergs, Conquered Conquistadors: The Lienzo de Quauhquechollan, a Nahua Vision of the Conquest of Guatemala (Leiden: CNWS Publications, 2004).

29. Robert M. Carmack and James L. Mondloch, eds., El título de Yax y otros documentos quichés de Totonicapán, Guatemala (Mexico City: UNAM, 1989); Ray A. Freeze, ed., A Fragment of an Early K'ekchi' Vocabulary, with Comments on the Cultural Content (Columbia: University of Missouri, Museum of Anthropology, 1975); Karen Dakin and Christopher Lutz, eds., Nuestro pesar, nuestra aflicción, tunetuliniliz tucucuca: Memorias en lengua náhuatl enviadas a Felipe II por indígenas del Valle de Guatemala hacia 1572 (Mexico City: UNAM, 1996).

30. René Acuña, ed., [Thesaurus verboru(m)]. Vocabulario de la lengua cakchiquel v(el) guatemalteca, nuevamente hecho y recopilado por summo estudio, travajo y emudición (Mexico City: UNAM, 1983); Judith M. Maxwell and Robert M. Hill II, eds. and trans., Kakchiquel Chronicles: The Definitive Edition (Austin: University of Texas Press, 2006). See also Matthew Restall, Lisa Sousa and Kevin Terraciano, eds., Mesoamerican Voices: Native Language Writings from Colonial Mexico, Oaxaca, Yucatan and Guatemala (New York: Cambridge University Press, 2005), and Laura Matthew, "El náhuatl y la identidad mexicana en la Guatemala colonial," Mesoamérica 40 (2000), 41-68. (I have not seen her Ph.D. dissertation, "Neither and Both: The Mexican Indian Conquistadors of Colonial Guatemala," University of Pennsylvania, 2004.)

31. William L. Sherman, Forced Native Labor in Sixteenth-Century Central America (Lincoln: University of Nebraska Press, 1979); Wendy Kramer, Encomienda Politics in Early Colonial Guatemala: Dividing the Spoils (Boulder: Westview Press, 1994); Horacio de Jesús Cabezas, Las reducciones indígenas en Guatemala durante el siglo XVI (Guatemala City: Universidad de San Carlos, 1974); Jorge Luján Muñoz, Agricultura, mercado y sociedad en el corregimiento del Valle de Guatemala, 1670-80 (Guatemala City: Universidad de San Carlos, 1988); Julio César Pinto Soria, Estructura agraria y asentamiento en la capitanía general de Guatemala (Guatemala City: Universidad de San Carlos, 1981); Salvador Rodríguez Becerra, Encomienda y conquista: Los inicios de la colonización en Guatemala (Seville: Universidad de Sevilla, 1977); Lawrence H. Feldman, Indian Payment in Kind: The Sixteenth-Century Encomiendas of Guatemala (Culver City, Calif.: Labyrinthos, 1992); and Ernesto Chinchilla 
Aguilar, Primer reparto de tierras para labranza: Guatemala, 1528-1538 (Guatemala City: Unión Tipográfica, 1984).

32. Stephen A. Webre, "The Social and Economic Bases of Cabildo Membership in Seventeenth-Century Santiago de Guatemala" (Ph.D. diss., Tulane University, 1980). On a similar subject, consult his "Antecedentes económicos de los regidores de Santiago de Guatemala, siglos XVI y XVII: Una élite colonial," in the book he edited, La sociedad colonial: Estudios regionales y locales (Antigua Guatemala: CIRMA, 1989), 189-219; José Manuel Santos Pérez, Elites, poder local y régimen colonial: El cabildo y los regidores de Santiago de Guatemala, 1700-1787 (South Woodstock, Vt.: Plumsock Mesoamerican Studies/Cádiz: Universidad de Cádiz, 1999); David Jickling, "The Vecinos of Guatemala in 1604," in Duncan Kinkead, ed., Estudios del Reino de Guatemala: Homenaje al Profesor S.D. Markman (Seville: Escuela de Estudios Hispano-Americanos, 1985), 77-100. The book by Christopher Lutz is Santiago de Guatemala, 1541-1773: City, Caste, and the Colonial Experience (Norman: University of Oklahoma Press, 1994). Several theses at the University of Costa Rica discuss the class and power structures of Cartago, and pertinent urban institutions.

33. Nicole Percheron, "Le pouvoir et les hommes: Les caciques de Rabinal au 16ème siècle," in Alain Ichon, ed., Rabinal et la valée moyenne du río Chixoy: Baja Verapaz, Guatemala (Paris: CNRS, 1981). A list of her publications is in the book brought out in her honor after her death, in Alain Breton, Vingt études sur le Mexique et le Guatemala, réunies à la mémoire de Nicole Percheron (Toulouse: Presses Universitaires du Mirail, 1991), 9-10. Also, Michel Bertrand, Terre et Société Coloniale: Les communautés Maya-Quiché de la region du Rabinal du XVIe, au XIXe siècle (Mexico City: Centre d'Etudes Mexicaines et Centroamericaines, 1987).

34. Lawrence H. Feldman, ed. and trans., Lost Shores, Forgotten Peoples: Spanish Explorations of the South East Maya Lowlands (Durham: Duke University Press, 2000); Stephen Webre, "La crisis de autoridad en el siglo XVII tardío: Centroamérica bajo la presidencia de don Jacinto de Barrios Leal, 1688-1695," Revista de Historia (Universidad Nacional de Heredia, Costa Rica), no. 27 (1993), 9-28. Grant D. Jones's two books are: Maya Resistance to Colonial Rule: Time and History on a Colonial Frontier (Albuquerque: University of New Mexico Press, 1989), and The Conquest of the Last Maya Kingdom (Stanford: Stanford University Press, 1998). For the approach to the unconquered area from Chiapas, see Jan de Vos, La paz de Dios y del Rey: La conquista de la Selva Lacandona, 1521-1821 (Mexico City: Colección Ceiba, Gobierno del Estado de Chiapas, 1980).

35. Barbara Elizabeth Jones Borg, Ethnohistory of the Sacatepéques Cakchiquel Maya, ca. 1450-1690 A.D. (Ph.D. diss., University of Missouri-Columbia,1986); Anne Cox Collins, Colonial Jacaltenango, Guatemala: The Formation of a Corporate Community (Ph.D. diss., Tulane University, 1980); Robert M. Hill II and John Monaghan, Continuities in Highland Maya Social Organization: Ethnohistory in Sacapulas, Guatemala (Philadelphia: University 
of Pennsylvania Press, 1987); Oscar H. Horst, "La utilización de archivos eclesiásticos en la reconstrucción de la historia demográfica de San Juan Ostuncalco," Mesoamérica 22 (1991), 211-231; W. George Lovell, Conquest and Survival in Colonial Guatemala: A Historical Geography of the Cuchumatán Highlands, 1500-1821. 3rd ed. (Montréal: McGill-Queen's University Press, 2005); two essays by Jorge Luján Muñoz, "Cambios en la estructura familiar de los indígenas pokomames de Petapa (Guatemala) en la primera mitad del siglo XVI," Mesoamérica 10 (1985), 355-369 and "Fundación de villas de ladinos en Guatemala en el ultimo tercio del siglo XVIII," Revista de Indias 36, nos. 145-146 (1976), 51-81; Sandra L. Orellana, The Tzutujil Mayas: Continuity and Change, 1250-1630 (Norman: University of Oklahoma Press, 1984); Jean Piel, Sajcabajá: Muerte y resurrección de un pueblo de Guatemala, 1500-1970 (Guatemala City: Seminario de Integración Social, 1989); Thomas T. Veblen, "Forest Preservation in the Western Highlands of Guatemala," Geographical Review 68, no. 4 (1978), 417-434; and Zamora, Los mayas de las tierras altas. (No doubt worthy of inclusion here is Robert M. Hill II, Colonial Cakchiquels: Highland Maya Adaptations to Spanish Rule, 1600-1700 [Fort Worth: Harcourt Brace Jovanovich, 1992], which I have not yet read.) The following book should not be ignored although it does not quite fit this category, Francisco de Solano, Pervivencia y transformación de la sociedad indígena guatemalteca durante la administración borbónica (Madrid: Ediciones Cultura Hispánica, 1974).

36. Isabel Rodas Núñez, De españoles a ladinos: Cambio social y relaciones de parentesco en el altiplano central colonial guatemalteco (Guatemala City: Ediciones ICAPI, 2004). A useful study of Indian town government, and how it changed over time, is Lina Barrios, La alcaldía indigena en Guatemala: Epoca colonial, 1500-1821 (Guatemala City: Universidad Rafael Landívar, Instituto de Investigaciones Económicas y Sociales, 1996).

37. Adriaan C. Van Oss, Catholic Colonialism: A Parish History of Guatemala, 1524-1821 (Cambridge: Cambridge University Press, 1986), and the same author's "Pueblos y parroquias en Suchitepéques colonial," Mesoamérica 7 (1984), 161-179. See also Edward O'Flaherty, Iglesia y sociedad en Guatemala, 1524-1563 (Seville: Universidad de Sevilla, 1984). We have already noted the de Vos critique of the chronicler Remesal. Van Oss added a study of the tedious but valuable Fray Francisco Vázquez, "Vázquez's Chronicle as a Source for the History of Religion and Architecture in Colonial Guatemala," in his posthumous Church and Society in Spanish America (Amsterdam: Aksant, 2003), 25-44. Carmelo Sáenz de Santa María, with his customary thoroughness, contributed a long and exhaustive study of another chronicler, Francisco Antonio de Fuentes y Guzmán, in "El escritor D. Francisco Antonio de Fuentes y Guzmán, criollo y patriota," Anales de la Academia de Geografia e Historia de Guatemala 53 (1980), 13-136. Several Guatemalan graduate theses discuss the lives and works of local bishops. Helpful to the researcher are the following: Siang Aguado de Seidner, "Los comienzos de la Guatemala colonial a través de las cartas 
(1534-1569) de su Obispo Francisco Marroquín" (Tésis de Licenciatura, Universidad de San Carlos, 1978), and Silvia Consuelo García Nájera de Pinillos, "Juan Bautista Alvarez de Toledo (1655-1725): Obispo de Chiapas y Guatemala" (Tésis de Licenciatura, Universidad del Valle, 1988). The late Manuel Rubio Sánchez wrote extensively on forts and ports, as we shall later see. Typical is his Historia de la fortaleza y puerto de San Fernando de Omoa (Guatemala City: Departamento de Información y Divulgación del Ejército, 1987).

38. See my comments on this paradox in MacLeod, "Paradojas e incógnitas en la historia colonial de San Salvador y Sonsonate," in Ana Margarita Gómez and Sajid Alfredo Herrera, comps., Mestizaje, poder y sociedad: Ensayos de historia colonial de las provincias de San Salvador y Sonsonate (San Salvador: FLACSO, 2003), 215-222.

39. Pedro Antonio Escalante Arce, Códice Sonsonate, Crónicas hispánicas, 2 vols. (San Salvador: CONCULTURA, 1992).

40. Diego García de Palacio, Carta-relación de Diego García de Palacio a Felipe II sobre la Provincia de Guatemala, 8 de marzo de 1576: Relación y forma que el Licenciado Palacio, oidor del la real audiencia de Guatemala, hizo para los que hubiesen de visitar, contar, tasar y repartir en las provincias de este distrito, María del Carmen León Cázares, paleographer (Mexico City: UNAM, 1983).

41. The works of Barón Castro and Lardé y Larín are included in the bibliography at the end of this book.

42. Pedro Escalante Arce, Los tlaxcaltecas en Centro América (San Salvador: Colección Biblioteca de Historia Salvadoreña, 2002).

43. José Antonio Fernández M., Pintando el mundo de azul: El auge añilero y el mercado centroamericano, 1750-1810 (San Salvador: Colección Biblioteca de Historia Salvadoreña, 2003); Manuel Rubio Sánchez, Historia del añil o xiquilite en Centro América, 2 vols. (San Salvador: Ministerio de Educación, 1976). Rubio Sánchez also wrote a prosopography and administrative study of the colony, in Alcaldes mayores: Historia de los alcaldes mayores, justicias mayores, gobernadores intendentes, intendentes corregidores, y jefes politicos de la Provincia de San Salvador, San Miguel y San Vicente, 2 vols. (San Salvador: Ministerio de Educación, 1979).

44. William R. Fowler,Jr., The Cultural Evolution of Ancient Nahua Civilizations: The Pipil-Nicarao of Central America (Norman: University of Oklahoma Press, 1989). Also his Caluco: Historia y arqueología de un pueblo pipil en el siglo XVI (San Salvador: Fundación Interamericana, 1995).

45. Santiago Montes, Etnohistoria de El Salvador, el guachival centroamericano: Cofradias, hermandades y guachivales, 2 vols. (San Salvador: Ministerio de Educación, 1977).

46. Gómez and Herrera, Mestizaje. Essays 1 and 3 by Paul Lokken and Mauricio Meléndez Obando (pp. 3-27 and 47-69, respectively) discuss the presence of a black population.

47. Linda Newson, The Cost of Conquest: Indian Decline in Honduras Under Spanish Rule (Boulder: Westview Press, 1986), and her "Labor in the Colo- 
nial Mining Industry of Honduras, The Americas 39, no. 2 (1982), 185-203. While mostly eighteenth century in coverage, the following book has plenty of information on the earlier period: Luis Pedro Taracena Arriola, Ilusión minera y poder político: La alcaldía mayor de Tegucigalpa, siglo XVII (Tegucigalpa: Editorial Guaymuras, 1998). See also, Mario Felipe Martínez, Apuntamientos para una historia colonial de Tegucigalpa y su alcaldía mayor (Tegucigalpa: Editorial Universitaria, 1982). For one of María de Los Angeles Chaverri's presentations at the various congresses of Central American historians, see her "El repartimiento de trabajo como causa de la protesta social en Honduras colonial: El caso Texiguat" (1 ${ }^{\text {st }}$ congress, Tegucigalpa, 1992).

48. Mario Felipe Martínez, ed., Documentos. Historia de Honduras (Tegucigalpa: Editorial Universitaria, 1983), and his Los últimos días de Lempira y otros documentos: El conquistador español que venció a Lempira (Tegucigalpa: Editorial Universitaria, 1983). See also Héctor M. Leyva, Documentos coloniales de Honduras (Tegucigalpa: Centro de Publicaciones Obispado de Choluteca/CEHDES, 1991). On the church, there is José Reina Valenzuela, Historia eclesiástica de Honduras, 2 vols. (Tegucigalpa: Centro de Publicaciones, Obispado de Choluteca, 1975, 1990); and Marcos Carías, La iglesia católica en Honduras, 1492-1975 (Tegucigalpa: Editorial Guaymuras, 1991). I have not yet seen Edwin Aguiluz Milla, ed., Iglesia y sociedad colonial en Honduras: Documentos del siglo XVI (Tegucigalpa: Colección Subirana, 1994). Nancy Johnson Black has written on The Frontier Mission and Social Transformation in Western Honduras: The Order of Our Lady of Mercy, 1525-1773 (Leiden: E. J. Brill, 1995); Anne M. Chapman has collected scattered contributions into Los hijos del copal y de la candela, 2 vols. (Mexico: UNAM: Centre d'Etudes Mexicaines et Centroamericaines, 1985-1986); and Atanasio Herranz has contributed his huge, magisterial, and prize-winning work on the history of Indian languages and official language policy, Estado, sociedad y lenguaje: La política linguística en Honduras (Tegucigalpa: Instituto Hondureño de Antropología e Historia/Editorial Guaymuras, 1996).

49. Mesoamérica 42 (2001). The essays by Melida Velásquez (pp. 199222) and Breny Mendoza (pp. 256-278) discuss slavery and the black population presence in Honduras. The list of young Honduran historians, not all students of the colony and no longer complete, of course, can be found in note 6 , p. xi of the issue.

50. Craig L. Dozier, Nicaragua's Mosquito Shore: The Years of British and American Presence (University: University of Alabama Press, 1985); José María García Añoveros, "Presencia franciscana en la Taguzgalpa y la Tologalpa (La Mosquitia)," Mesoamérica 15 (1988), 47-78; Robert A. Naylor, Penny Ante Imperialism: The Mosquito Shore and the Bay of Honduras, 1600-1914: A Case Study of British Informal Empire (Rutherford, N.J.: Farleigh Dickinson University Press, 1989); Barbara Potthast, Die Mosquitoküste in Spannungsfeld britischer und spannischer Politik, 1502-1821 (Cologne: Bühlau, 1988); Germán Romero Vargas, Historia de la costa atlántica (Managua: CIDCAUCA, 1996); and Douglas Thompson, "Frontiers of Identity: The Atlantic 
Coast and the Formation of Honduras and Nicaragua, 1764-1894" (Ph.D. diss., University of Florida, 2001).

51. Germán Romero Vargas, Las estructuras sociales de Nicaragua en el siglo XVIII (Managua: Vanguardia, 1987).

52. Linda A. Newson, Indian Survival in Colonial Nicaragua (Norman: University of Oklahoma Press, 1987); David R. Radell, "The Indian Slave Trade and Population of Nicaragua during the Sixteenth Century," in William M. Denevan, ed., The Native Population of the Americas in 1492 (Madison: University of Wisconsin Press, 1976), 67-76; and Dan Stanislawski, The Transformation of Nicaragua: 1519-1548 (Berkeley: University of California Press, Ibero-Americana 54, 1983).

53. Jaime Incer Barquero, Descubrimiento y exploración del Río San Juan (Managua: HISPAMER, 1999). Note his edited volume, Piratas y aventureros en las costas de Nicaragua: Crónicas de fuentes originales (Managua: Fundación VIDA, 2003). The Radell and Parsons contribution can be found in the main bibliography of this book. Another book on the Pacific port of Realejo is Manuel Rubio Sánchez, Historia de El Realejo (Managua: Banco de América, 1975).

54. Carlos Meléndez Chaverri, Conquistadores y pobladores: Orígenes histórico-sociales de los costarricenses (San José: Editorial Universidad Estatal a Distancia, 1982). And his Costa Rica: Tierra y poblamiento en la colonia (San José: Editorial Costa Rica, 1977).

55. Víctor Hugo Acuña Ortega, Historia económica y social de Costa Rica, 1750-1950 (San José: Editorial Porvenir, 1991); Héctor Pérez Brignoli, La población de Costa Rica según el obispo Thiel (San José: Universidad de Costa Rica, 1988). Apropos also is the second edition of the book by Víctor Sanabria Martínez, Bernardo Augusto Thiel, Segundo Obispo de Costa Rica: Apuntamientos históricos (San José: Editorial Costa Rica, 1982). See also Juan Solórzano Fonseca, "Costa Rica colonial: Una síntesis interpretativa," in Costa Rica colonial: Tres ensayos (San José: CSUCA, 1984), 15-43, and his El comercio exterior de Costa Rica durante la primera mitad del siglo XVII (San José: Universidad de Costa Rica, 1988). Several students at the Universidad de Costa Rica have composed theses on urban life in Cartago. Typical of this work is the publication by María Elizet Payne Iglesias, Actividades artesanales en Cartago, siglo XVII: Maestros, oficiales y apréndices (San José: Universidad de Costa Rica, 1987). For cacao in Matina see Philip S. Mac-Leod, "Auge y estancamiento de la producción de cacao en Costa Rica, 1660-95," in Anuario de Estudios Centroamericanos 22, no. 1 (1996), 83-107; and Carlos Rosés Alvarado, "El ciclo del cacao en la economía colonial de Costa Rica, 1650-1794," Mesoamérica 4 (1982), 249-278. On smuggling see Juan Solórzano Fonseca, "El comercio de Costa Rica durante el declive del comercio español y el desarrollo del contrabando ingles: Período 1690-1750," Anuario de Estudios Centroamericanos 20, no. 2 (1994), 71-119.

56. Claudia Quirós, La era de la encomienda (San José: Editorial de la Universidad de Costa Rica, 1990), which deals with Indian labor. The 
prize-winning book by Rina Cáceres, Negros, mulatos, esclavos y libertos en la Costa Rica del siglo XVII (Mexico City: Instituto Panamericano de Geografía e Historia, 2000), complements Quirós by dealing with black labor. For revolts read Claudio Barrantes, "Los caminos de Pablo Presbere en la época colonial," Comisión Nacional de Nomenclatura: Relación de Actividades (San José: Ministerio de Cultura, Juventud y Deportes, 1985), 27-67. There is a brief but interesting account of the Presbere campaign in Carlos Roberto López Leal, "Una rebelión indígena en Talamanca: Pablo Presbere y el alzamiento general de 1709" (Tésis de Licenciatura, Universidad de San Carlos, 1973). We can find Juan Solórzano Fonseca, once again, in his "Indígenas insumisos, frailes y soldados: Talamanca y Guatuso, 1660-1821," Anuario de Estudios Centroamericanos 23, nos. 1-2 (1997), 141-197; and Luis Fernando Sibajá Chacón, "Los indígenas de Nicoya bajo el dominio español, 1522-1560," Estudios Sociales Centroamericanos (San José) 32 (1982), $32-47$.

57. Ana Paulina Malavassi Aguilar, Entre la marginalidad social y los origenes de la salud pública: Leprosos, curanderos y facultativos en el Valle Central de Costa Rica, 1784-1845 (San José: Editorial de la Universidad de Costa Rica, 2003).

58. See vol. 1 of Castillero Calvo's three-volume Historia general de Panamá (Panama City: Comité Nacional del Centenario de la República, 2004), and his La ruta transistmica y las comunicaciones maritimas hispanas, siglos XVI a XIX (Panama City: Editora Renovación, 1984). See also the two books by Mena García, La sociedad de Panamá en el siglo XVI (Seville: Excma. Diputación Provincial de Sevilla, 1984) and Temas de historia panameña (Panama City: Editorial Universitaria, 1996). For the Portobelo fairs, read Enriqueta Vila Vilar, Las ferias de Portobelo: Apariencia y realidad del comercio con Indias (Seville: Escuela de Estudios Hispano-Americanos, 1982). Also Christopher Ward, Imperial Panama: Commerce and Conflict in Isthmian America, 1550-1800 (Albuquerque: University of New Mexico Press, 1993).

59. Omar Jáen Suárez, Un estudio de historia rural panameña: La region de los llanos de Chirú (Panama City: Editorial Mariano Arosemena del Instituto Nacional de Cultura, 1991). It is worthwhile to consult his older book, $E l$ hombre y la tierra en Natá de 1700 a 1850 (Panama City: Editorial Universitaria, 1971).

60. Carol F. Jopling, ed., Indios y negros en Panamá en los siglos XVI y XVII: Selecciones de los documentos del Archivo General de Indias (Antigua Guatemala: CIRMA, 1994).

61. Rubio Sánchez, Historia de la fortaleza, for his work on Omoa. Another of his books on fortifications is Historia del fuerte de San Rafael de Matamoros (Guatemala City: Editorial "José de Pineda Ibarra," 1982). Other works include Víctor Cruz Reyes et al., Fuerte de San Fernando de Omoa: Epoca colonial (Tegucigalpa: Instituto Hondureño de Antropología e Historia, 1985); and the more recent Juan Manuel Zapatero, El fuerte de San Fernando y las fortificaciones de Omoa (Tegucigalpa: INAH, 1997). Zapatero's general 
studies on fortifications include La fortificación abaluartada en América (San Juan, Puerto Rico: Instituto de Cultura Puertorriqueña, 1978). We already have noted Rubio Sánchez's work on Realejo. He composed several other studies of colonial ports.

62. Lawrence H. Feldman, "Disasters, Natural and Otherwise, and Their Effects upon Population Centers in the Reino de Guatemala," in Kinkead, ed., Estudios, 49-60; Cleto González Víquez, Temblores, terremotos, inundaciones y erupciones volcánicas en Costa Rica, 1608-1910, 2nd ed. (Cartago: Editorial Tecnológica de Costa Rica, 1994). For a specific earthquake and its results, see Rafael Eugenio Garavito Pontacq, "Los terremotos de 1717 en Santiago de Guatemala: Consideraciones sociales, económicas y políticas" (Tésis de Licenciatura, Universidad del Valle, 1999). For the Saint-Lu essay, see the bibliography at the end of the book.

63. Thomas Fiehrer, "Slaves and Freedmen in Colonial Central America: Rediscovering a Forgotten Black Past," Journal of Negro History 64, no. 1 (1979), 39-57; Michael D. Olien, "Black and Part-Black Populations in Colonial Costa Rica: Ethnohistorical Resources and Problems," Ethnohistory 27, no. 1 (1980), 13-29.

64. Paul Lokken in his "Marriage as Slave Emancipation in Seventeenth-Century Rural Guatemala," The Americas 58, no. 2 (2001), 175-200, provides a list (note 8, p. 177) of the theses at the Universidad de San Carlos and the Universidad del Valle on the black population of colonial Guatemala, and of other publications on the subject. For legal aspects, consult Beatriz Palomo de Lewin, "La esclavitud negra en Guatemala durante los siglos XVI y XVII," in Chinchilla Aguilar, Historia general de Guatemala 2, 275-286, and especially 281-282. See the Lokken essay "Marriage," and Lutz, Santiago de Guatemala. Robinson Herrera's book is Natives, Europeans, and Africans in Sixteenth-Century Santiago de Guatemala (Austin: University of Texas Press, 2003).

65. For example, Paul Lokken, "Undoing Racial Hierarchy: Mulattos and Militia Service in Colonial Guatemala, SECOLAS Annals 31 (1999), 25-36.

66. Webre, "Antecedents," and Jickling, "The Vecinos." Jorge Luján Muñoz and his students have completed several works on colonial government monopolies, or estancos, all of them later than the years of interest here, but see, for example, Magda Leticia González Sandoval, "El estanco de bebidas embrigantes en Guatemala, 1753-1860" (Tésis de Licenciatura, Universidad del Valle, 1990). Sometimes the Real Audiencia prevailed against the cabildo of Santiago, e.g., Patch, Maya Revolt, especially pp. 85-86. A recent study of these power struggles, in which the cabildo often holds its own, is by Santos Pérez, Elites, poder local y régimen colonial.

67. Richmond F. Brown, Juan Fermin de Aycinena: Central American Colonial Entrepreneur, 1729-1796 (Norman: University of Oklahoma Press, 1997).

68. Wortman, Government and Society. Palma Murga makes much the 
same points in his "Economía y sociedad en Centroamérica, 1680-1750," in Torres Rivas, Historia general, vol. 2, El régimen colonial, 219-306. Both Herrera, Natives, Europeans, and Africans, and Lutz, Santiago de Guatemala, describe a commercially active Santiago.

69. Van Oss, Catholic Colonialism. See also his "A Far Kingdom: Central American Autarky at the End of the Eighteenth Century," in his Church and Society, 1-24.

70. See note 64 for details on these two books. Clearly, apart perhaps from the first few decades after the Spanish invasion, I disagree with the mentality or "worldview" ascribed to the colonial elite in Pilar Sanchiz Ochoa, Los hidalgos de Guatemala. Realidad y apariencia en un sistema de valores (Seville: Universidad de Sevilla, 1976).

\section{Bibliography}

Acuña, René, ed. Relaciones geográficas del siglo XVI: Guatemala. Mexico City: UNAM, 1982.

guatemalteca, nuevamente hecho y recopilado por summo estudio, travajo y erudición. Mexico City: UNAM, 1983.

Acuña Ortega, Víctor Hugo. Historia económica y social de Costa Rica, 17501950. San José: Editorial Porvenir, 1991.

Aguado de Seidner, Siang. "Los comienzos de la Guatemala colonial a través de las cartas (1534-1569) de su Obispo Francisco Marroquín." Tésis de Licenciatura, Universidad de San Carlos, 1978.

Aguiluz Milla, Edwin, ed. Iglesia y sociedad colonial en Honduras: Documentos del siglo XVI. Tegucigalpa: Colección Subirana, 1994.

Alvarez, Gloria, and Hamlet García. Fuentes históricas de Centro América de la época colonial. Managua: Biblioteca del Instituto Histórico Centroamericano, 1994.

Alvarez-Lobos Villatoro, Carlos Alfonso, and Ricardo Toledo Palomo. Libro de los pareceres de la Real Audiencia de Guatemala, 1571-1655. Guatemala City: Academia de Geografia e Historia de Guatemala, Biblioteca "Goathemala," 32, 1996.

Amelang, James S., ed. and trans. A Journal of the Plague Year: The Diary of the Barcelona Tanner Miquel Parets, 1651. New York: Oxford University Press, 1991.

Amerlinck de Bontempo, Mari José. “Conquista espiritual y económica: La formación de haciendas de frailes dominicos en Chiapas." Mesoamérica 20 (1990), 215-229.

Ara, Fr. Domingo de. Vocabulario de lengua tzeldal según el orden de Copanabastle. Ed. by Mario Humberto Ruz. Mexico City: UNAM, 1986.

Aramoni Calderón, Dolores. Los refugios de lo sagrado: Religiosidad, conflicto y resistencia entre los zoques de Chiapas. Mexico City: Consejo Nacional para la Cultura y las Artes, 1992. 
Argüello Solórzano, Federico, and Carlos Molina Argüello, eds. Monumenta centroamericae historica: Colección de documentos y materiales para el estudio de la historia de la vida de los pueblos de la América Central. 11 vols. Managua: Banco Central de Nicaragua, 1997-2004.

Asselbergs, Florine G. L. Conquered Conquistadors: The Lienzo of Quauhquechollan, a Nahua Vision of the Conquest of Guatemala. Leiden: CNWS Publications, 2004.

Barrantes, Claudio. "Los caminos de Pablo Presbere en la época colonial." In Comisión Nacional de Nomenclatura: Relación de Actividades. San José: Ministerio de Cultura, Juventud y Deportes, 1985, 27-67.

Barrios, Lina. La alcaldía indígena en Guatemala: Epoca colonial, 1500-1821. Guatemala City: Universidad Rafael Landívar/Instituto de Investigaciones Económicas y Sociales, 1996.

Bertrand, Michel. Terre et Société Coloniale: Les communautés Maya-Quiché de la region du Rabinal du XVIe, au XIXe siècle. Mexico City: Centre d'Etudes Mexicaines et Centroamericaines, 1987.

Black, Nancy Johnson. The Frontier Mission and Social Transformation in Western Honduras: The Order of Our Lady of Mercy, 1525-1773. Leiden: E. J. Brill, 1995.

Boletín del Archivo Histórico Diocesano. San Cristóbal de Las Casas, intermittently since 1983.

Bonaccorsi, Nélida. El trabajo obligatorio indígena en Chiapas, siglo XVI: Los altos y Soconusco. Mexico City: UNAM, 1990.

Borg, Barbara Elizabeth Jones. Ethnohistory of the Sacatepéques Cakchiquel Maya, ca. 1450-1690 A.D. Ph.D. diss., University of Missouri-Columbia, 1986.

Breton, Alain. Vingt études sur le Mexique et le Guatemala, réunies à la mémoire de Nicole Percheron. Toulouse: Presses Universitaires du Mirail, 1991.

Brown, Richmond F. Juan Fermín de Aycinena: Central American Colonial Entrepreneur, 1729-1796. Norman: University of Oklahoma Press, 1997.

Cabezas, Horacio de Jesús. Las reducciones indígenas en Guatemala durante el siglo XVI. Guatemala City: Universidad de San Carlos, 1974.

Cáceres, Rina. Negros, mulatos, esclavos y libertos en la Costa Rica del siglo XVII. Mexico City: Instituto Panamericano de Geografía e Historia, 2000.

Cal Montoya, José Edgardo, "La historia cultural en Guatemala: Un itinerario para recorrer. Reflexiones historiográficas," Diálogos: Revista Electrónica de Historia (San José) 6, no. 2 (August 2005-February 2006), 83-97.

Camargo R., Marcela, and Yolanda Marco Serra, eds. Memoria del VI Congreso Centroamericano de Historia, Panamá, 22-26.7.2002. Panama City: Facultad de Humanidades/Departamento de Historia, 2005.

Carías, Marcos. La iglesia católica en Honduras, 1492-1975. Tegucigalpa: Editorial Guaymuras, 1991.

Carmack, Robert M. The Quiché Mayas of Utatlán: The Evolution of a Highland Guatemala Kingdom. Norman: University of Oklahoma Press, 1981. 
Carmack, Robert M., and James L. Mondlock, eds. El título de Yax y otros documentos quichés de Totonicapán, Guatemala. Mexico City: UNAM, 1989.

Carmack, Robert M., John D. Early, and Christopher H. Lutz, eds. The Historical Demography of Highland Guatemala. Albany: State University of New York, Institute for Mesoamerican Studies, 1982.

Castillero Calvo, Alfredo. Historia general de Panamá. 3 vols. Panama City: Comité Nacional del Centenario de la República, 2004.

- La ruta transístmica y las comunicaciones marítimas hispanas, siglos XVI a XIX. Panama City: Editora Renovación, 1984.

Chapman, Anne M. Los hijos del copal y de la candela. 2 vols. Mexico City: UNAM, Centre d'Etudes Mexicaines et Centroamericaines, 1985-1986.

Chaverri, María de los Angeles. "El repartimiento de trabajo como causa de la protesta social en Honduras colonial: El caso Texiguat." Paper presented at First Congress of Central American Historians, Tegucigalpa, 1992.

Chinchilla Aguilar, Ernesto. Blasones y heredades: Historia de Centroamérica, vol. 2. Guatemala City: J. de Pineda Ibarra, 1975.

- Primer reparto de tierras para labranza: Guatemala, 1528-1538. Guatemala City: Unión Tipográfica, 1984.

Ciudad Suárez, Milagros. Los dominicos: Un grupo de poder en Chiapas y Guatemala, siglos XVI y XVII. Seville: Escuela de Estudios Hispano-Americanos, 1996.

Collins, Anne Cox. Colonial Jacaltenango, Guatemala: The Formation of a Corporate Community. Ph.D. diss., Tulane University, 1980.

Cruz Reyes, Víctor, et al. Fuerte de San Fernando de Omoa: Epoca colonial. Tegucigalpa: Instituto Hondureño de Antropología e Historia, 1985.

Dakin, Karen, and Christopher Lutz, eds. Nuestro pesar, nuestra aflicción, tunetuliniliz tucucuca: Memorias en lengua náhuatl enviadas a Felipe II por indigenas del Valle de Guatemala hacia 1572. Mexico City: UNAM, 1996.

de Vos, Jan. Catálogo de los documentos históricos que se conservan en el fondo llamado "Provincia de Chiapas" del Archivo General de Centroamérica, Guatemala. 2 vols. in 3. San Cristóbal de Las Casas, Chiapas: Centro de Estudios Indígenas/UNACH, 1985.

- Los enredos de Remesal: Ensayo sobre la conquista de Chiapas. Mexico City: Consejo Nacional para la Cultura y las Artes, 1992.

- La paz de Dios y del Rey: La conquista de la Selva Lacandona, 15211821. Mexico City: Colección Ceiba, Gobierno del Estado de Chiapas, 1980.

- Vivir en frontera: La experiencia de los indios de Chiapas. Mexico City: CIESAS, 1994.

Denevan, William M., ed. The Native Population of the Americas in 1492. Madison: University of Wisconsin Press, 1976.

Dozier, Craig L. Nicaragua's Mosquito Shore: The Years of British and American Presence. University: University of Alabama Press, 1985.

Enríquez Macías, Genoveva. "Nuevos documentos para la demografía 
histórica de la Audiencia de Guatemala a finales del siglo XVII." Mesoamérica 17 (1989), 121-183.

Escalante Arce, Pedro Antonio. Códice Sonsonate, Crónicas hispánicas. 2 vols. San Salvador: CONCULTURA, 1992.

- Los tlaxcaltecas en Centro América. San Salvador: Colección Biblioteca de Historia Salvadoreña, 2002.

Falla, Juan José, ed. Extractos de escrituras públicas. Archivo General de Centroamérica. 3 vols. Guatemala City: Museo Popol Vuh de la Universidad Francisco Marroquín, 1994-2001.

Feldman, Lawrence H. "Disasters, Natural and Otherwise, and Their Effects upon Population Centers in the Reino de Guatemala." In Kinkead, ed., Estudios, 49-60.

- Indian Payment in Kind: The Sixteenth-Century Encomiendas of Guatemala. Culver City, Calif.: Labyrinthos, 1992.

- ed. and trans. Lost Shores, Forgotten Peoples: Spanish Explorations of the South East Maya Lowlands. Durham: Duke University Press, 2000.

Fernández M., José Antonio. Pintando el mundo de azul: El auge añilero y el mercado centroamericano, 1750-1810. San Salvador: Colección Biblioteca de Historia Salvadoreña, 2003.

Fiehrer, Thomas. "Slaves and Freedmen in Colonial Central America: Rediscovering a Forgotten Black Past." Journal of Negro History 64, no. 1 (1979), 39-57.

Fonseca Corrales, Elizabeth. Centroamérica: Su historia. San José: FLACSO/ EDUCA, 1996.

Fowler, William R., Jr. Caluco: Historia y arqueología de un pueblo pipil en el siglo XVI. San Salvador: Fundación Interamericana, 1995.

- The Cultural Evolution of Ancient Nahua Civilizations: The Pipil-Nicarao of Central America. Norman: University of Oklahoma Press, 1989.

Freeze, Ray A., ed. A Fragment of an Early K'ekchi' Vocabulary, with Comments on the Cultural Content. Columbia: Museum of Anthropology, University of Missouri-Columbia, 1975.

Garavito Pontacq, Rafael Eugenio. "Los terremotos de 1717 en Santiago de Guatemala: Consideraciones sociales, económicas y políticas." Tésis de Licenciatura, Universidad del Valle, 1999.

García Añoveros, José María. "Presencia franciscana en la Taguzgalpa y la Tologalpa (La Mosquitia)." Mesoamérica 15 (1988), 47-78.

García de León, Antonio. Resistencia y utopia: Memorial de agravios y crónica de revueltas y profecías acaecidas en la provincia de Chiapas durante los últimos quinientos años de su historia. 2 vols. Mexico City: Ediciones Era, 1985.

García de Palacio, Diego. Carta-relación de Diego García de Palacio a Felipe II sobre la Provincia de Guatemala, 8 de marzo de 1576: Relación y forma que el Licenciado Palacio, oidor del la real audiencia de Guatemala, hizo para los que hubiesen de visitar, contar, tasar y repartir en las provincias de este distrito. María del Carmen León Cázares, paleographer. Mexico City: UNAM, 1983.

García Nájera de Pinillos, Silvia Consuelo. "Juan Bautista Alvarez de To- 
ledo (1655-1725): Obispo de Chiapas y Guatemala." Tésis de Licenciatura, Universidad del Valle, 1988.

Gasco, Janine. "The Colonial Economy in the Province of Soconusco." In Barbara Voorhies, ed., Ancient Trade and Tribute: Economies of the Soconusco Region of Mesoamerica. Salt Lake City: University of Utah Press, 1989, 287-303.

. "Economic History of Ocelocalco, a Colonial Soconusco Town." In J. Daniel Rogers and Samuel L. Wilson, eds., Ethnohistory and Archaeology. Approaches to Postcontact Changes in the Americas. New York: Plenum Press, 1993.

Gerhard, Peter. The Southeast Frontier of New Spain. Princeton: Princeton University Press, 1979.

Gómez, Ana Margarita, and Sajid Alfredo Herrera, eds. Mestizaje, poder y sociedad: Ensayos de historia colonial de las provincias de San Salvador y Sonsonate. San Salvador: FLACSO, 2003.

González Sandoval, Magda Leticia. "El estanco de bebidas embrigantes en Guatemala, 1753-1860." Tésis de Licenciatura, Universidad del Valle, 1990.

González Víquez, Cleto. Temblores, terremotos, inundaciones y erupciones volcánicas en Costa Rica, 1608-1910. 2nd ed. Cartago: Editorial Tecnológica de Costa Rica, 1994.

Gosner, Kevin. Soldiers of the Virgin: The Moral Economy of a Colonial Mayan Rebellion. Tucson: University of Arizona Press, 1992.

Hall, Carolyn, and Héctor Pérez Brignoli (John V. Cotter, cartographer). Historical Atlas of Central America. Norman: University of Oklahoma Press, 2003.

Herranz, Atanasio. Estado, sociedad y lenguaje: La política linguística en Honduras. Tegucigalpa: Instituto Hondureño de Antropología e Historia/ Editorial Guaymuras, 1996.

Herrera, Robinson. Natives, Europeans, and Africans in Sixteenth-Century Santiago de Guatemala. Austin: University of Texas Press, 2003.

Hill, Robert M., II. Colonial Cakchiquels: Highland Maya Adaptations to Spanish Rule, 1600-1700. Fort Worth: Harcourt Brace Jovanovich, 1992.

Hill, Robert M., II, and John Monaghan. Continuities in Highland Maya Social Organization: Ethnohistory in Sacapulas, Guatemala. Philadelphia: University of Pennsylvania Press, 1987.

Horst, Oscar H. "La utilización de archivos eclesiásticos en la reconstrucción de la historia demográfica de San Juan Ostuncalco.” Mesoamérica 22 (1991), 211-231.

Ichon, Alain, ed., Rabinal et la valée moyenne du río Chixoy: Baja Verapaz, Guatemala. Paris: CNRS, 1981.

Incer Barquero, Jaime. Descubrimiento y exploración del Río San Juan. Managua: HISPAMER, 1999.

, ed. Piratas y aventureros en las costas de Nicaragua: Crónicas de fuentes originales. Managua: Fundación VIDA, 2003. 
Jáen Suárez, Omar. Un estudio de historia rural panameña: La región de los llanos de Chirú. Panama City: Editorial Mariano Arosemena del Instituto Nacional de Cultura, 1991.

—_. El hombre y la tierra en Natá de 1700 a 1850. Panama City: Editorial Universitaria, 1971.

Jickling, David. "The Vecinos of Guatemala in 1604." In Kinkead, ed., Estudios del Reino de Guatemala, 77-100.

Jones, Grant D. The Conquest of the Last Maya Kingdom. Stanford: Stanford University Press, 1998.

- Maya Resistance to Colonial Rule: Time and History on a Colonial Frontier. Albuquerque: University of New Mexico Press, 1989.

Jopling, Carol F., ed. Indios y negros en Panamá en los siglos XVI y XVII: Selecciones de los documentos del Archivo General de Indias. Antigua Guatemala: CIRMA, 1994.

Kinkead, Duncan, ed. Estudios del Reino de Guatemala: Homenaje al Profesor S. D. Markman. Seville: Escuela de Estudios Hispano-Americanos, 1985.

Kramer, Wendy. Encomienda Politics in Early Colonial Guatemala: Dividing the Spoils. Boulder: Westview Press, 1994.

Lenkersdorf, Gudrun. Génesis histórico de Chiapas, 1522-1532: El conflicto entre Portocarrero y Mazariegos. Mexico City: UNAM, 1993.

- Repúblicas de indios. Pueblos mayas en Chiapas, siglo XVI. Mexico City: UNAM, 2001.

León Cázares, María del Carmen. Un levantamiento en nombre del Rey Nuestro Señor: Testimonios indígenas relacionados con el visitador Francisco Gómez de Lamadriz. Mexico City: UNAM, 1988.

León Cázares, María del Carmen, Mario Humberto Ruz, and José Alejos García. Del Katún al siglo: Tiempos de colonialismo y resistencia entre los mayas. Mexico City: Consejo Nacional para la Cultura y las Artes, 1992.

Leyva, Héctor M. Documentos coloniales de Honduras. Tegucigalpa: Centro de Publicaciones, Obispado de Choluteca/CEHDES, 1991.

Lokken, Paul. "Marriage as Slave Emancipation in Seventeenth-Century Rural Guatemala." The Americas 58, no. 2 (2001), 175-200.

- . "Undoing Racial Hierarchy: Mulattos and Militia Service in Colonial Guatemala." SECOLAS Annals 31 (1999), 25-36.

López Gómez, Pedro. El Archivo General de Centroamérica (Ciudad Guatemala): Informe. Madrid: ANABAD, 1991.

López Leal, Carlos Roberto. "Una rebelión indígena en Talamanca: Pablo Presbere y el alzamiento general de 1709." Tésis de Licenciatura, Universidad de San Carlos, 1973.

Lovell, W. George. Conquest and Survival in Colonial Guatemala: A Historical Geography of the Cuchumatán Highlands, 1500-1821. 3rd ed. Montréal: McGill/Queen's University Press, 2005.

Lovell, W. George, and Christopher H. Lutz. Demografia e imperio. Guatemala City: Editorial Universitario, 2000.

- Demography and Empire: A Guide to the Population History of Span- 
ish Central America, 1500-1821. Boulder: Westview Press, Dellplain Latin American Studies, No. 33, 1995.

Luján Muñoz, Jorge. Agricultura, mercado y sociedad en el Corregimiento del Valle de Guatemala, 1670-80. Guatemala City: Universidad de San Carlos, 1988.

- "Cambios en la estructura familiar de los indígenas pokomames de Petapa (Guatemala) en la primera mitad del siglo XVI." Mesoamérica 10 (1985), 355-369.

- "Fundación de villas de ladinos en Guatemala en el último tercio del siglo XVIII." Revista de Indias 36, nos. 145-146 (1976), 51-81.

- Guía del Archivo General de Centro América. Guatemala City: Ministerio de Educación, 1982.

- , gen. ed. Historia general de Guatemala. 6 vols. Guatemala City: Asociación de Amigos del País, 1993-1996.

Lutz, Christopher. Santiago de Guatemala, 1541-1773: City, Caste, and the Colonial Experience. Norman: University of Oklahoma Press, 1994.

MacLeod, Murdo J. "La espada de la iglesia: Excomunión y la evolución de la lucha por el control político y económico en Chiapas colonial, 1545-1700." Mesoamérica 20 (1990), 199-213.

- "Motines y cambios en las formas de control económico y político: Los acontecimientos de Tuxtla, 1693.” Mesoamérica 28 (1994), 231-251.

- "Paradojas e incógnitas en la historia colonial de San Salvador y Sonsonate." In Gómez and Herrera, eds., Mestizaje, poder y sociedad, 215-222.

MacLeod, Murdo J., and Robert Wasserstrom, eds. Spaniards and Indians in Southeastern Mesoamerica: Essays on the History of Ethnic Relations. Lincoln: University of Nebraska Press, 1983.

MacLeod, Philip S. "Auge y estancamiento de la producción de cacao en Costa Rica, 1660-95." Anuario de Estudios Centroamericanos 22, no. 1 (1996), 83-107.

Malavassi Aguilar, Ana Paulina. Entre la marginalidad social y los origenes de la salud pública: Leprosos, curanderos y facultativos en el Valle Central de Costa Rica, 1784-1845. San José: Editorial de la Universidad de Costa Rica, 2003.

Mariana, Juan de. La tiranía y los derechos del pueblo. Mexico City: Secretaría de Educación Pública, 1948.

Markman, Sidney David, ed. and comp. Colonial Central America: A Bibliography. Tempe: Center for Latin American Studies, Arizona State University, 1977.

Martínez, Mario Felipe. Apuntamientos para una historia colonial de Tegucigalpa y su alcaldía mayor. Tegucigalpa: Editorial Universitaria, 1982.

$\longrightarrow$, ed. Documentos. Historia de Honduras. Tegucigalpa: Editorial Universitaria, 1983.

— - ed. Los últimos días de Lempira y otros documentos: El conquistador español que venció a Lempira. Tegucigalpa: Editorial Universitaria, 1983. 
Martínez Peláez, Severo. Motines de indios. Guatemala City: Ediciones en Marcha, 1991.

Matthew, Laura. "El náhuatl y la identidad mexicana en la Guatemala colonial." Mesoamérica 40 (2000), 41-68.

- "Neither and Both: The Mexican Indian Conquistadors of Colonial Guatemala." Ph.D. diss., University of Pennsylvania, 2004.

Maxwell, Judith M., and Robert M. Hill II, eds. and trans. Kakchiquel Chronicles: The Definitive Edition. Austin: University of Texas Press, 2006.

McCreery, David. Rural Guatemala, 1760-1940. Stanford: Stanford University Press, 1994.

Meléndez Chaverri, Carlos. Conquistadores y pobladores: Orígenes histórico-sociales de los costarricenses. San José: Editorial Universidad Estatal a Distancia, 1982.

- Costa Rica: Tierra y poblamiento en la colonia. San José: Editorial Costa Rica, 1977.

Mena García, María del Carmen. La sociedad de Panamá en el siglo XVI. Seville: Excma. Diputación Provincial de Sevilla, 1984.

- Temas de historia panameña. Panama City: Editorial Universitaria, 1996.

Mesoamérica 42 (2001). Issue devoted to Honduras.

Montes, Santiago. Etnohistoria de El Salvador, el guachival centroamericano: Cofradias, hermandades y guachivales. 2 vols. San Salvador: Ministerio de Educación, 1977.

Nájera Coronado, Martha Ilia. La formación de la oligarquía criolla en Ciudad Real de Chiapas: El caso Ortés de Velasco. Mexico City: UNAM, 1993.

Naylor, Robert A. Penny Ante Imperialism: The Mosquito Shore and the Bay of Honduras, 1600-1914: A Case Study of British Informal Empire. Rutherford, N.J.: Farleigh Dickinson University Press, 1989.

Newson, Linda. The Cost of Conquest: Indian Decline in Honduras under Spanish Rule. Boulder: Westview Press, 1986.

- Indian Survival in Colonial Nicaragua. Norman: University of Oklahoma Press, 1987.

- "Labor in the Colonial Mining Industry of Honduras." The Americas 39, no. 2 (1982), 185-203.

Núñez de la Vega, Francisco. Constituciones diocesanas del Obispado de Chia$p a$. Ed. by María del Carmen León Cázares and Mario Humberto Ruz. Mexico City: UNAM, 1988.

O'Flaherty, Edward. Iglesia y sociedad en Guatemala, 1524-1563. Seville: Universidad de Sevilla, 1984.

Olien, Michael D. "Black and Part-Black Populations in Colonial Costa Rica: Ethnohistorical Resources and Problems." Ethnohistory 27, no. 1 (1980), 13-29.

Orellana, Sandra L. The Tzutujil Mayas: Continuity and Change, 1250-1630. Norman: University of Oklahoma Press, 1984.

Ortiz de la Tabla, Javier, Bibiano Torres Ramírez, and Enriqueta Vila Vilar, 
eds. Cartas de cabildos hispanoamericanos: Audiencia de Guatemala. 2 vols. Seville: Escuela de Estudios Hispano-Americanos, 1984-1986.

Palma Murga, Gustavo. "Economía y sociedad en Centroamérica, 16801750." In Torres Rivas, Historia general, vol. 2: El régimen colonial, 219-306.

depositado en la Escribanía de Cámara del Supremo Gobierno de la República de Guatemala: Segunda Parte, que comprende el índice alfabético general. Mexico City: CIESAS, 1991.

Palomo de Lewin, Beatriz. "La esclavitud negra en Guatemala durante los siglos XVI y XVII." In Chinchilla Aguilar, Historia general, vol. 2, 275-286.

Pastor, Rodolfo. Historia de Centroamérica. Mexico City: El Colegio de México, 1988.

Patch, Robert W. Maya Revolt and Revolution in the Eighteenth Century. Armonk, N.Y.: M .E. Sharpe, 2002.

Payne Iglesias, María Elizet. Actividades artesanales en Cartago, siglo XVII: Maestros, oficiales y apréndices. San José: Universidad de Costa Rica, 1987.

Percheron, Nicole. "Le pouvoir et les hommes: Les caciques de Rabinal au 16ème siècle." In Ichon, ed., Rabinal et la valée moyenne du río Chixoy.

Pérez Brignoli, Héctor. Breve historia de Centroamérica. Madrid: Alianza Editorial, 1985.

- La población de Costa Rica según el obispo Thiel. San José: Universidad de Costa Rica, 1988.

Piel, Jean. Sajcabajá: Muerte y resurrección de un pueblo de Guatemala, 1500 1970. Guatemala City: Seminario de Integración Social, 1989.

Pinto Soria, Julio César. Estructura agraria y asentamiento en la capitanía general de Guatemala. Guatemala City: Universidad de San Carlos, 1981.

Potthast, Barbara. Die Mosquitoküste in Spannungsfeld britischer und spannischer Politik, 1502-1821. Cologne: Bühlau, 1988.

Quirós, Claudia. La era de la encomienda. San José: Editorial de la Universidad de Costa Rica, 1990.

Radell, David R. "The Indian Slave Trade and Population of Nicaragua during the Sixteenth Century." In Denevan, ed., The Native Population, 67-76.

Reina Valenzuela, José. Historia eclesiástica de Honduras. 2 vols. Tegucigalpa: Centro de Publicaciones, Obispado de Choluteca, 1975, 1990.

Restall, Matthew, Lisa Sousa, and Kevin Terraciano, eds. Mesoamerican Voices: Native Language Writings from Colonial Mexico, Oaxaca, Yucatan and Guatemala. New York: Cambridge University Press, 2005.

Rodas Núñez, Isabel. De españoles a ladinos: Cambio social y relaciones de parentesco en el altiplano central colonial guatemalteco. Guatemala City: Ediciones ICAPI, 2004.

Rodríguez Becerra, Salvador. Encomienda y conquista: Los inicios de la colonización en Guatemala. Seville: Universidad de Sevilla, 1977.

Romero Vargas, Germán. Las estructuras sociales de Nicaragua en el siglo XVIII. Managua: Vanguardia, 1987. 
Historia de la costa atlántica. Managua: CIDCA-UCA, 1996.

Rosés Alvarado, Carlos. "El ciclo del cacao en la economía colonial de Costa Rica, 1650-1794." Mesoamérica 4 (1982), 249-278.

Rubio Sánchez, Manuel. Alcaldes mayores: Historia de los alcaldes mayores, justicias mayores, gobernadores intendentes, intendentes corregidores, y jefes politicos de la Provincia de San Salvador, San Miguel y San Vicente. 2 vols. San Salvador: Ministerio de Educación, 1979.

- Historia del añil o xiquilite en Centro América. 2 vols. San Salvador: Ministerio de Educación, 1976.

- Historia de El Realejo. Managua: Banco de América, 1975.

- Historia del fuerte de San Rafael de Matamoros. Guatemala City: Editorial "José de Pineda Ibarra," 1982.

- Historia de la fortaleza y puerto de San Fernando de Omoa. Guatemala City: Departamento de Información y Divulgación del Ejército, 1987.

Ruz, Mario Humberto. Copanaguastla en un espejo: Un pueblo tzeltal en el virreinato. San Cristóbal de Las Casas, Chiapas: Centro de Estudios Indígenas, UNACH, 1985.

nal de Paris. Mexico City: UNAM, 1989.

- ed. Memoria eclesial guatemalteca, visitas pastorales. 2 vols. Mexico City: UNAM, 2002.

- Savia india, floración ladina: Apuntes para una historia de las fincas comitecas (siglos XVIII y XIX). Mexico City: Consejo Nacional para la Cultura y las Artes, 1992.

Sáenz de Santa María, Carmelo. "El Escritor D. Francisco Antonio de Fuentes y Guzmán, criollo y patriota." Anales de la Academia de Geografia e Historia de Guatemala 53 (1980), 13-136.

Saint-Lu, André. "El poder colonial y la iglesia frente a la sublevación de los indígenas zendales de Chiapas en 1712." Mesoamérica 12 (1986), 23-33.

Sanabria Martínez, Víctor. Bernardo Augusto Thiel, Segundo Obispo de Costa Rica: Apuntamientos históricos. 2nd ed. San José: Editorial Costa Rica, 1982.

Sanchiz Ochoa, Pilar. Los hidalgos de Guatemala. Realidad y apariencia en un sistema de valores. Seville: Universidad de Sevilla, 1976.

Santos Pérez, José Manuel. Elites, poder local y régimen colonial: El cabildo y los regidores de Santiago de Guatemala, 1700-1787. South Woodstock, Vt.: Plumsock Mesoamerican Studies/Cádiz: Universidad de Cádiz, 1999.

Sherman, William L. Forced Native Labor in Sixteenth-Century Central America. Lincoln: University of Nebraska Press, 1979.

Sibajá Chacón, Luis Fernando. "Los indígenas de Nicoya bajo el dominio español, 1522-1560." Estudios Sociales Centroamericanos (San José) 32 (1982), 32-47.

Simpson, Lesley B. "Mexico's Forgotten Century." See the main bibliography of this book. 
Solano, Francisco de. Pervivencia y transformación de la sociedad indígena guatemalteca durante la administración borbónica. Madrid: Ediciones Cultura Hispánica, 1974.

- Tierra y sociedad en el reino de Guatemala. Guatemala City: Editorial Universitaria, 1979.

Solórzano Fonseca, Juan. "El comercio de Costa Rica durante el declive del comercio español y el desarrollo del contrabando ingles: Período 1690-1750." Anuario de Estudios Centroamericanos 20, no. 2 (1994), 71119.

- El comercio exterior de Costa Rica durante la primera mitad del siglo XVIII. San José: Universidad de Costa Rica, 1988.

—_. "Costa Rica colonial: Una síntesis interpretativa." In Costa Rica colonial: Tres ensayos. San José: CSUCA, 1984, 15-43.

- "Indígenas insumisos, frailes y soldados: Talamanca y Guatuso, 1660-1821." Anuario de Estudios Centroamericanos 23, nos. 1-2 (1997), 141-197.

Stanislawski, Dan. The Transformation of Nicaragua: 1519-1548. Berkeley: University of California Press, Ibero-Americana 54, 1983.

Suñe Blanco, Beatriz. La documentación del cabildo secular de Guatemala (siglo XVI): Estudio diplomático y valor etnográfico. Seville: Universidad de Sevilla, 1984.

Taracena Arriola, Luis Pedro. Ilusión minera y poder político: La alcaldía mayor de Tegucigalpa, siglo XVIII. Tegucigalpa: Editorial Guaymuras, 1998.

Thompson, Douglas. "Frontiers of Identity: The Atlantic Coast and the Formation of Honduras and Nicaragua, 1764-1894." Ph.D. diss., University of Florida, 2001.

Torres Rivas, Edelberto, ed. Historia general de Centroamérica. 6 vols. Madrid: Comunidades Europeas/FLACSO, 1993-1997.

Torres Rivas, Edelberto, and María Eugenia Gallardo. Para entender Centroamérica: Resumen bibliográfico, 1960-84. San José: Instituto Centroamericano de Documentación e Integración Social, 1985.

Van Oss, Adriaan. Catholic Colonialism: A Parish History of Guatemala, 15241821. Cambridge: Cambridge University Press, 1986.

_. "Pueblos y parroquias en Suchitepéques colonial." Mesoamérica 7 (1984), 161-179.

—. "Vázquez's Chronicle as a Source for the History of Religion and Architecture in Colonial Guatemala." In Van Oss, Church and Society in Spanish America. Amsterdam: Aksant, 2003, 25-44.

Veblen, Thomas T. "Forest Preservation in the Western Highlands of Guatemala." Geographical Review 68, no. 4 (1978), 417-434.

- "Native Population Decline in Totonicapán, Guatemala." In Carmack, Early, and Lutz, eds., Historical Demography, 81-102.

Vila Vilar, Enriqueta. Las ferias de Portobelo: Apariencia y realidad del comercio con Indias. Seville: Escuela de Estudios Hispano-Americanos, 1982.

Viqueira Albán, Juan Pedro. Indios rebeldes e idólatras; Dos ensayos históricos 
sobre la rebelión india de Cancuc, Chiapas, acaecida en el año 1712. Mexico City: CIESAS, 1997.

- María de la Candelaria, india natural de Cancuc. Mexico City: Fondo de Cultura Económica, 1993.

—_. "Tributo y sociedad en Chiapas, 1680-1721." Historia Mexicana 44, no. 2 (1994), 237-267.

Viqueira Albán, Juan Pedro, and Mario Humberto Ruz, eds. Chiapas: Los rumbos de otra historia. Mexico City: CIESAS, 2002.

Voorhies, Barbara, ed. Ancient Trade and Tribute: Economies of the Soconusco Region of Mesoamerica. Salt Lake City: University of Utah Press, 1989.

Ward, Christopher. Imperial Panama: Commerce and Conflict in Isthmian America, 1550-1800. Albuquerque: University of New Mexico Press, 1993.

Wasserstrom, Robert. Class and Society in Central Chiapas. Berkeley: University of California Press, 1983.

Webre, Stephen A. "Antecedentes económicos de los regidores de Santiago de Guatemala, siglos XVI y XVII: Una élite colonial." In Webre, ed., La sociedad colonial: Estudios regionales y locales. Antigua Guatemala: CIRMA, 1989, 189-219.

—_ "La crisis de autoridad en el siglo XVII tardío: Centroamérica bajo la presidencia de don Jacinto de Barrios Leal, 1688-1695." Revista de Historia (Universidad Nacional de Heredia, Costa Rica), no. 27 (1993), 9-28.

- "The Social and Economic Bases of Cabildo Membership in Seventeenth-Century Santiago de Guatemala." Ph.D. diss., Tulane University, 1980.

Werner, Patrick S. Ethnohistory of Early Colonial Nicaragua: Demography and Encomiendas of the Indian Communities. Albany: State University of New York, Institute of Mesoamerican Studies, 2000.

Woodward, Ralph Lee. Central America: A Nation Divided. New York: Oxford University Press, 1985.

Wortman, Miles L. Government and Society in Central America, 1680-1840. New York: Columbia University Press, 1982.

Zamora Acosta, Elías. Los mayas de las tierras altas en el siglo XVI: Tradición y cambio en Guatemala. Seville: Diputación Provincial de Sevilla, 1985.

Zapatero, Juan Manuel. La fortificación abaluartada en América. San Juan: Instituto de Cultura Puertorriqueña, 1978.

- El fuerte de San Fernando y las fortificaciones de Omoa. Tegucigalpa: INAH, 1997. 